NBER WORKING PAPER SERIES

\author{
CAREER AND FAMILY: COLLEGE \\ WOMEN LOOK TO THE PAST
}

Claudia Goldin

Working Paper No. 5188

\author{
NATIONAL BUREAU OF ECONOMIC RESEARCH \\ 1050 Massachusetts Avenue \\ Cambridge, MA 02138 \\ July 1995
}

Presented at the ILR-Cornell Institute for Labor Market Policies Conference "Gender and Family Issues in the Workplace," Cornell University, April 21-23, 1995. This paper derives from "The Meaning of College in the Lives of American Women: The Past Hundred Years," National Bureau of Economic Research Working Paper No. 4099. I repeat the acknowledgements made in that paper by thanking the students of Economics 1356 (Spring 1991) for furnishing the stimulus for this study and the participants of public lectures at numerous colleges and universities, among them Wellesley College, Bates College, Simmons College, Bard College, Tufts University, University of Pittsburgh, and the University of Iowa, for their comments. The earlier paper was presented at the Conference on Women's Human Capital and Development, May 18-22, 1992, Bellagio, Italy, and I acknowledge the helpful comments of the discussants, John Strauss and Barbara Torrey, as well as those of the other participants. I thank Boris Simkovich for his research assistance on the earlier version, and Rohini Somanathan and Linda Tuch for their research assistance on this version. Larry Katz commented on both drafts. I was prompted to write this paper by Fran Blau's comments on the previous version: "I would love to see you do a similar type of analysis for 'the intermediate cohort' [cohort IV] -- i.e., our cohort!" This paper is part of NBER's research programs in the Development of the American Economy and Labor Studies. Any opinions expressed are those of the author and not those of the National Bureau of Economic Research.

(C) 1995 by Claudia Goldin. All rights reserved. Short sections of text, not to exceed two paragraphs, may be quoted without explicit permission provided that full credit, including (C) notice, is given to the source. 


\title{
CAREER AND FAMILY: COLLEGE WOMEN LOOK TO THE PAST
}

\begin{abstract}
Recent college graduate women express frustration regarding the obstacles they will face
\end{abstract} in combining career and family. Tracing the demographic and labor force experiences of four cohorts of college women across the past century allows us to observe the choices each made and how the constraints facing college women loosened over time.

No cohort of college graduate women in the past had a high success rate in combining family and career. Cohort I (graduating c. 1910) had a 50\% rate of childlessness. Whereas cohort III (graduating c. 1955) had a high rate of childbearing, it had initially low labor force participation. Cohort IV (graduating c. 1972) provides the most immediate guide for today's college women and is close to the end of its fertility history. It is also a cohort that can be studied using the N.L.S. Young Women. In 1991, when the group was 37 to 47 years old, 28\% of the sample's college graduate (white) women had yet to have a first birth. The estimates for career vary from $24 \%$ to $33 \%$ for all college graduate women in the sample. Thus only $13 \%$ to $17 \%$ of the group achieved "family and career" by the time it was about 40 years old. Among those who attained career, $50 \%$ were childless. Cohort IV contains a small group of women who have combined family with career, but for most the goal remains elusive.

Claudia Goldin Department of Economics Harvard University Cambridge, MA 02138 and NBER 
College women today want both family and career. The experiences of previous cohorts serve as their guides, but none furnishes the example they want to follow. College women have succeeded in achieving parity in numbers with their male counterparts, they are receiving educations of about equal quality, and they are continuing in professional and graduate schools more than ever before. ${ }^{1} \quad$ Yet full equality still seems an elusive goal and there is palpable frustration.

I describe here the demographic and economic fates of prior cohorts of college women, each a possible model for today's college woman. Tradeoffs of substantial consequence were made by past generations of college women, compromises the present generation appears unwilling to make. Despite shifting tradeoffs and changing gender inequality in demographic and economic outcomes, each generation of female college graduates set the stage for the next. To comprehend how we have arrived at the choices faced by the current generation, we must understand change across the past hundred years.

\section{Five Cohorts: A Summary}

I consider five cohorts of college graduates each about 20 years in duration (see Table 1). The differences among them and the progression of tradeoffs can be summarized in the following manner. In cohort I -- a group graduating around 1910 and born around 1890 -college presented a stark set of alternatives between family and career. For most women in this group it was one or the other, and when the selection was a career, it almost always involved teaching. Although college men in this generation married and had families at about the same rate as men without higher education, college women in this generation were set apart from

\footnotetext{
${ }^{1}$ The ratio of men to women in professional schools was 23.4 in 1960 but 1.66 in 1988 . The ratio in graduate schools was 2.48 in 1960 but 0.90 in 1988 (U.S. Department of Health, Education, and Welfare, Digest 1988; OFE 1960).
} 
their non-college counterparts. More than $50 \%$ of college-graduate women in this cohort either did not marry or, if they did so, did not have children. ${ }^{2}$ College women were a small fraction of the young population, but college men were almost equally so. Although both were drawn from the upper echelons of American wealth and standing, there is evidence that differences in the demographic experiences between college women and their non-college counterparts were largely due to a "treatment effect" of college, rather than to selection bias. That is, the college experience affected them.

The second cohort -- graduating around 1933 and born around 1910 - attained higher marriage rates than its predecessor cohort. But the proportion of the relevant population attending college for four or more years did not increase much. That is, the marriage and childbearing rate of this cohort increased from the previous one, but the apparent selection into college did not change. Mary McCarthy's autobiographical The Group which concerns the lives of eight Vassar women in the class of 1933, opens at the wedding of one in the group just six weeks after her graduation. That would not have been the opening scene for a novel about the previous cohort of college women. The members of this second cohort not only married, they also entered the work place just after graduation. They remained at work for several years, frequently with aspirations, rarely fulfilled, of a full career. "They were a different breed than those of the previous decade," wrote McCarthy of her group, "not one did not propose to work this coming fall." But family eventually intervened. I characterize cohort II as attaining "job then family" and view it as a bridge from I to III. The full blossoming of the movement of college women into the American mainstream came after the 1940s with cohort III. I will not go into any further detail on cohort II.

\footnotetext{
${ }^{2}$ The $50 \%$ figure is for the cohort born c. $1890: 31.1 \%(=\%$ never married $)+[27.6 \%$ (= \% having no child ren by age $35-44$ years) $\times 68.9 \%$ (= \% ever married)].
} 
College offered the women in cohort III -- graduating around 1955 and born around 1933 -- the opportunity to have both family and paid employment. But the two were to be serially scheduled -- family came first, in terms of timing and priority, then employment. The employment of choice was, once again, teaching, for it allowed such serial timing without a large penalty. It was a profession one could "fall back on," because teaching would always be in demand and teaching credentials generally remained valid during job interruptions. But college also afforded the women of this cohort the opportunity to marry a college-educated man.

One might ask of many of the women from cohort III whether the direct (pecuniary) returns to college justified the tuition and opportunity costs of their four years of higher education. The answer was that it generally did not, but that college allowed them to tap into the market for college-educated men. Not only did women who attended college stand a considerably higher chance of marrying a college-educated man, they also married the higher income-generating man from among the college-educated group as well as from among the highschool educated group. As college became more accessible to the masses and as America became swept away by the post-World War II revival of family, college women married and had children at almost the same rates as their non-college contemporaries. Despite all appearances to the contrary, however, the college woman of the 1950s set the stage for the events of the 1970s -- the resurgence of feminism.

The women of cohort IV - graduating around 1972 and born around 1950 -- are the first for whom a considerable fraction have considered the career path. They are currently between 38 and 51 years old and their childbirth and marital histories are nearly complete. A portion of the cohort -- those who were 14 to 24 years old in 1968 -- were sampled in the first N.L.S. (National Longitudinal Survey of) Young Women and are studied in detail below. I find that among those who attained the B.A. degree, 29\% had not yet had their first birth by 1991 when 
the group was 37 to 47 years old. ${ }^{3}$ Although about $26 \%$ to $33 \%$ were on a "career track," using a very generous definition concerning their earnings in the late 1980s relative to those of comparable men, only 13 to $17 \%$ had achieved "family and career" by that time.

College appears to be offering the women in cohort V - graduating after 1980 and born since 1958 - the opportunity for true equality with their male counterparts. College women today reject the choice of "family or career," the options of cohort I, and "family then job," that of cohort III. And they are uncomfortable with the choice of "career then family," that of many in cohort IV who just preceded them. They are unwilling to schedule events serially and thereby risk forfeiting one of them. They can find no previous cohort that provides a suitable model and only a small fraction of women in any of the cohorts who have. Many of the doors that were closed to previous generations of college women are now open. Yet the graduates of the past decade seem a discontent group. ${ }^{4}$

\section{College Attendance and Graduation Data for Men and Women}

Before exploring the basis for the characterizations just offered, it is instructive to examine the percentages of males and females who attended and graduated from college across this century. The fewer who attended college, the more they could be a highly self-selected sample from among the entire population. Because I would like to isolate the "treatment effect" of college, it is imperative to understand the process of selection into college.

Prior to 1940, the proportions of men and women who attended college were low, but

\footnotetext{
${ }^{3}$ The figure is $28.8 \%$ for no first births by 1991 for white women with $\geq 16$ years of education ( $28.6 \%$ for white women with B.A. degrees) conditional on being in the sample in 1991.

${ }^{4}$ This conclusion is based, admittedly, on a small sample -- those in my Economics 1356 class, other Harvard undergraduates with whom I have contact, and the impressions of many others who teach generation $X$.
} 
the percentages were remarkably similar by sex. ${ }^{5}$ Among those born around 1890 (from 1886 to 1895 ), for example, $9.5 \%$ of the men attended college for at least one year whereas $8.9 \%$ of the women did, and attendance figures are only slightly higher for cohorts born around 1900 (1895 to 1900; see Figure 1 and Appendix Table A1). ${ }^{6}$ Graduation rates are somewhat further apart, when the definition of graduating college is attending for four or more years (see Figure 2 and Appendix Table A1). ${ }^{7}$ Of the cohort born around $1890,5.0 \%$ of men graduated college whereas $3.4 \%$ of women did. Attendance rates were far higher for women relative to their graduation rates but only in part because two-year colleges are included in the data. ${ }^{8}$ Until recently far fewer women than men who attended college actually graduated. By the cohort born in 1905, even graduation rates had narrowed between the sexes; the ratio of graduating males to females was 1.24. The trend, however, was not to continue.

The two lines in Figures 1 and 2 diverge with cohorts born around 1910, and they remain apart until the recent period. Some of the men in the cohorts born around 1920 delayed their college education during World War II; many others would not have received a college

\footnotetext{
${ }^{5}$ It should be noted at the very outset that in all of the empirical work that follows only white men and women are considered because of the considerably smaller number of nonwhites who attended college in the past.

${ }^{6}$ The percentage attending college may be exaggerated for the older cohorts although differences by sex could be accurate. I suspect the figures are exaggerated because the data for high school graduates are overstated in the 1940 census (see Goldin 1994).

${ }^{7}$ Both the graduation rates and the attendance rates are as of ages 45 to 54 or 55 to 64 years. See Figures 1 and 2 for sources and notes.

${ }^{8}$ In 1962, for example, two-year colleges accounted for $14 \%$ of all college enrollees for both males and females. Yet the ratio of graduation rates to attendance rates was $61 \%$ for males but $48 \%$ for females in the birth cohort of 1940 (see Appendix Table A1). Thus the differences in graduation rates between males and females must be accounted for by differential graduation from four-year colleges. The same is probably not the case for earlier cohorts. Graduation rates were much lower for women in the cohorts born before 1905, thus graduating before about 1927. A large fraction of the women in these cohorts who attended college were in teachers' colleges and normal schools, but it is difficult to separate the two-year normal schools from the four-year teachers' colleges in those years. Normal schools are of little importance after the 1940s.
} 
education were it not for the war. The GI Bill of Rights provided the first large dose of federal subsidization of college tuition and enticed a substantial fraction of men in their twenties and early thirties to return to school.

Large differences between men and women in college graduation rates persisted until the cohorts born in the $1950 \mathrm{~s}$. The ratio of male to female graduates increased to 1.79 for the cohort born around 1930. It declined to 1.62 in the next ten years but was still far higher than it had been earlier in the century. Attendance rates differed less, in part because men, whose tuition was subsidized after World War II, completed college at greater rates than did women and in part because women attended two-year schools in somewhat greater numbers. The gap in both graduation and attendance eventually disappeared by the cohorts born in the early 1960s. By 1980 more women than men were receiving B.A.s.

Thus cohort I attended college when few men and women went to college but when they attended in roughly similar proportions to their populations. Cohort III attended college when the ratio of males to females in attendance was greater than at any time in the past hundred years. Finally, cohort $\mathrm{V}$ is attending college in an era of the greatest gender equality in both attendance and graduation rates.

\section{A Framework for Understanding Change in Family and Career Decisions}

A simple framework is constructed to demonstrate how the constraints facing college women changed across the past century. Changing constraints not changing tastes, I believe, served to alter the decisions of college women with regard to family and career.

The framework contains three periods, each of which should be thought of as between 7 to 10 years in length. All periods occur after the woman achieves her highest grade or degree (a B.A. ,or higher degree, in the case of college women). In each period a woman's time 
endowment, (T), can be spent employed full-time (e), with family full-time (f), or involved in some combination of the two, each part-time. ${ }^{9}$ Utility is a function of $\mathrm{T}^{\mathrm{f}}$, time spent with family, and income, $Y$ :

$$
\mathrm{U}=\mathrm{U}\left(\mathrm{T}^{\mathrm{f}}, \mathrm{Y}\right)
$$

For college women, each period at full-time work can be used to earn at least:

$$
\mathrm{Y}_{\mathrm{i}}^{\mathrm{c}}=\mathrm{w}_{\mathrm{i}}^{\mathrm{c}} \mathrm{T}_{\mathrm{i}}
$$

If a college woman works full-time for two consecutive periods she obtains a return to job experience (r), and she obtains another return ( $r$ ) if she works full-time for three periods. Lifetime earnings (in the case of no discounting) are simply:

$$
Y^{c} \leq w^{c} \cdot T_{1}+w^{c} \cdot T_{2}(1+r)+w^{c} \cdot T_{3}(1+r)^{2}
$$

A "career" is defined as working full-time for at least two consecutive periods, thus accruing returns to job experience. ${ }^{10}$ Women who do not graduate college earn each period, at most:

$$
Y^{n}{ }_{i}=w^{n} T_{i} \text {, where } w^{c}>w^{n} \text {. }
$$

No return to job experience accrues to the non-college graduate women, and therefore the woman who does not graduate college cannot have a "career." "Family" is defined as having at least one child. Each child requires a minimum fraction $(k)$ of a time period that must be spent with family. Women cannot engage in "family time" unless they have children.

I consider the lifetime budget constraint of the woman (without possible husband's income). ${ }^{11}$ Figure $3 a$ depicts this constraint under the simple assumptions just made. If the

\footnotetext{
9 "Full-time," here, means without interruption (non-intermittently) and full-time, in the usual manner (meaning more than 35 to 40 hours/week).

${ }^{10}$ Career earnings are akin to a large bonus at the end of the second and, possibly, third years.

${ }^{11}$ The model can expanded to account for why the women in cohort III, for example, went to college even when the increase in their earnings did not result in a sufficiently high rate of return. If college for this cohort gained them entry to a lucrative "marriage market," as I will claim below, the budget constraint will be shifted upwards.
} 
woman spends each of the three periods full-time at one of the two activities (paid employment or family) there are eight rational combinations. The ninth combination produces an interior point; $(e, f, e)$, meaning two employment spells interrupted by family, is dominated by either (f, $e, e)$ or $(e, e, f)$ because of the returns to continuous employment. ${ }^{12}$ The budget constraint is invariant to the timing of the decisions, under the assumptions given. ${ }^{13}$

The points on and within the budget constraint contain every possible value of the lifetime allocation of a college woman's time. Beginning with the right-most point, ( $f, f, f$ ) represents spending all periods full-time with family and earning no income. Moving to the left, a woman can trade-off any portion of this time to work in the market at wage rate $\mathrm{w}^{\mathrm{c}}$. The point $(f, f, e)$ gives $w^{c} \cdot T$ income and $2 T$ in family time. Moving farther to the left shows that when the woman works for two consecutive periods she reaps a return of $\mathbf{r}^{\mathrm{r}} \mathbf{w}^{\mathrm{c}} \cdot \mathbf{T}$ and the budget constraint has a break. This point can represent either $(e, e, f)$ or $(f, e, e)$; as noted previously, the budget constraint is unaffected by the timing. Note that all points between $(f, f, f)$ and the break can be achieved by trading time with the market. Because children require only $\mathrm{T} \cdot \mathrm{k}$, all the points to the break are consistent with family and "job," although not necessarily with "family and career."

Allocations between $T_{3} \cdot k$ and $T_{3}$ are of interest because that is the range of "family and career." After the woman is in the labor force for two consecutive period, units of $\mathrm{T}$ earn at the

\footnotetext{
${ }^{12} \mathrm{By}(\mathrm{e}, \mathrm{f}, \mathrm{e})$, for example, I mean: the first period in the labor force full time, the second at home with family full time, and the third and final period in the labor force full time. The allocation produces an interior point because the gains from job experience accrue only when experience is continuous.

${ }^{13}$ The budget constraint may not be invariant when, as in this framework, there is a return to experience for a portion of the last period or a portion of the first, but the invariant portion will involve a "timing error," similar to the combination, $(e, f, e)$, that was excluded. That is, a woman can work two consecutive periods and have a child in either the first or the last period. The minimum time required for a child is $T \cdot k$, leaving $T \cdot(1-k)$ for paid employment. If the $T \cdot(1-k)$ portion is taken at the start of the first period, it earns at only $w^{c}$, and the budget constraint will not include the portion with slope $w^{c}(1+$ r).
} 
rate $w^{c}(1+r)$. The woman who remains in the labor force for the entire three periods earns the maximum income, and the budget constraint jumps to $(e, e, e)$. It would not be rational to spend a positive amount of time that was less than $T \cdot k$ on family and thus the budget constraint jumps at that point.

The budget constraint in Figure $3 a$ is been drawn under the assumptions that $T=7$ years, $k=0.5$, and $r=0.5$, a reasonable value if the return to experience is about $6 \%$ per year. ${ }^{14}$ The darkened portions of the budget constraint represent the career points. They include the (e, e, e) point, which is "career only," and also the segment between $(e, e, f)$ and $(e, e,[f \cdot k+e \cdot(1-k)]$, which is "family and career."

The budget constraint gives the set of choices facing college women today but not necessarily those available to college women of past generations. The women in cohort I were faced with a stark choice between two extreme points, $(f, f, f)$, that is $T_{3}$, and $(e, e, e)$ because married women generally did not work for pay. ${ }^{15}$ The budget constraint takes shape with cohorts II and III when married women began to work for pay after their children were grown. But it excluded the "family and career" portions. With cohort IV the "family and career" portion was added. All of the changes in the budget constraint were due to the greater acceptance of women in the labor force, not just college women, and in most professions.

How did college change the lives of these women? Without college the budget constraint is the line with slope $w^{n}$ in Figure $3 b$. With college, the budget constraint is first just the two extreme points, $(f, f, f)$ and $(e, e, e)$, then the line with slope $w^{c}$, and finally the broken line containing the "family and career" points. It is now clear why so many in the first cohort opted

\footnotetext{
${ }^{14}$ This is because $(1.06)^{7}=0.50$.

${ }^{15} \mathrm{Y}^{\max }$, for this cohort, could also be thought of as $Y^{\prime}$, which is full-time work for 3 periods but no career.
} 
for the (e, e, e) point even if they had the same preferences as the non-college graduate group who chose point N. And it is also transparent why, as the line became filled in, there was a large group shifting to a combination of "family and job," point III. It is equally clear why, when the budget constraint included the "family and career" segment the desired equilibrium shifted to IV. Figure $3 b$ shows that a set of homothetic indifference curves can generate the equilibrium combinations chosen by a majority of the college-graduate cohorts I, III, and IV. Changes in the constraints facing college-graduate women, and even without changing tastes or self-selection, can generate observations across the past hundred years regarding work, career, and family.

\section{Cohort I: "Family or Career"}

The women of cohort I completed their B.A. degrees between 1900 and 1920 . Although prior cohorts of female college graduates can be studied, the women of cohort I are the earliest for which data on education, occupation, fertility, marriage age, and husband's income can be found in the 1940 Public Use Micro-Data Sample (PUMS) of the federal population census.

The first college to open its doors to women was Oberlin in 1837 , but it was not until the 1850s that opportunities for women in higher education expanded, particularly with the establishment of female colleges. At that time, however, many of the institutions of higher learning open to women were not true colleges but were seminaries, often no more intellectually demanding than high schools and without rigorous entrance requirements. Only in the 1870 s and 1880s with the establishment of the finer women's colleges, such as Vassar and Smith, and with the opening of various state universities to women, did the era of women's higher education truly begin. By $191073 \%$ of all colleges were open to women, almost $80 \%$ of which

were coeducational institutions (Newcomer 1959, p. 37). Most of the women's colleges that had 
the minimum age requirement of sixteen years were upstanding institutions that endeavored to provide to women what other colleges were giving to men: they strove for equality of curriculum (Woody 1929). Most colleges and universities taught a liberal arts curriculum in which there were basically two courses of study - classical and scientific. Thus, women and men took very similar classes, even when they were not at the same institution.

Women's higher education had what Thomas Woody, the noted historian of education, viewed as an unanticipated consequence. By the 1890 s it was clear that college women were marrying at decidedly lower rates than were those who did not attend college, and that, even if they married, they were having considerably fewer children than their less-educated counterparts. The finding spawned an extensive literature for it was alarming to many in an era of growing nativism. ${ }^{16}$ They, and current researchers, have faced the same problem in trying to ascertain how much of the difference in demographic experiences was due to sample selection and how much was due to the treatment effect of college. Although definitive evidence on the subject has not yet been unearthed, there are two independent findings consistent with the interpretation that the differences were more a function of what college did for women than which women went to college.

That said, it should be noted that many of the previous studies of the nuptiality rates of college women were not based on nation-wide samples, but rather on alumni surveys. Most, but not all, were surveys of women in the elite colleges of the northeast, often women's colleges like Smith, Vassar, Radcliffe, Wellesley, and Bryn Mawr (see, for example, Van Kleek 1918). Not only were the studies biased in their selection of schools, often known for their low marriage rates, but marriage rates for relatively recent graduates were given with no adjustment for time since graduation. Estimates in the previous studies were biased both by virtue of composition

\footnotetext{
16 See Cookingham (1984) for references.
} 
and in terms of incompleteness of spell.

The 1940 PUMS affords a more universal view of the nuptiality of college women, although the bias here is probably in the opposite direction. By accepting the recollections of older women and using the percentage who listed themselves as "never married," it is likely that the fraction who claimed to have ever-married is overstated. Among those born around 1890, more than $30 \%$ never married by age $45 .{ }^{17}$ For those born around 1900 , about $25 \%$ never married by age 45 (see Table 2).

The woman who attended but did not graduate from college (or who graduated from a two-year college) stood a somewhat higher probability of marrying by age 45 . But the percentage never-marrying for either college group was considerably greater than for women who never attended college (see Table 2). The female college graduate born around 1890 was 4 times more likely to remain single than was her non-college counterpart $(31.1 \%$ against $7.8 \%)$. The same statistic for those born around 1880 is 3.7 (computed for women aged 55 to 64). College graduate women in the years from about 1900 to 1927 had lifetime marriage probabilities that were fully 20 percentage points lower than their non-college counterparts.

The general conclusion of the turn-of-the-century studies on nuptiality and college was that the college experience both caused and enabled women to have a lower marriage rate. College permitted women to be more discerning in their choice of lifestyle and husband. Further, the typical occupation for college graduate women, particularly in the East, was as a teacher in a private girls' school, and "there is no station in life (save that of a nun) so inimical to marriage as that of resident teacher in a girls' school" (Shinn 1895, p. 948). Finally, men, it was said, often disliked the intellectual woman. The possibility of sample selection was raised,

\footnotetext{
${ }^{17}$ I focus on college graduates to get around the problem that college attendance includes those at twoyear colleges and normal schools. I have assumed that women graduated from college at 22 years old, but that is generally a minimum, and the age for the earlier cohorts was probably much higher.
} 
and some noted that women who considered going to college formed a biased sample because they had not married young (Newcomer 1959, pp. 212-13). But the notion that the college woman would not have married anyhow was generally, though not entirely, dismissed.

Not only did the college woman of the early twentieth century have a lower probability of marrying, she also stood a much higher probability of not having children even if she married. Just under $30 \%$ of female college graduates who were 35 to 44 years old in 1940 (and were ever-married) recorded no lifetime births. The percentage was 1.72 times that of women with no college education and was 11.7 percentage points higher (see Table 3). Figure 4 graphs the percentage of ever-married (white) women having no births by age 35 to 44 for college graduates, those with no college, and high-school only graduates. ${ }^{18}$ Together with the data on marriage, those on children show that $50 \%$ of all female college graduates born from 1886 to 1895 either never married or had no children by the time they reached age 45 (see Figure 5).

The female college graduate around the turn of this century made a distinct choice between family and career. About $50 \%$ did not opt for husband and children, whereas only $22 \%$ of those who did not attend college took that route. ${ }^{19}$ The college woman of that era was twice as likely as the woman who did not attend college to take this atypical route in life. One is, therefore, led to ask what took the place of family.

Of those college graduate women who were 45 to 54 years old in 1940 and who had never married, $88.4 \%$ were in the labor force in 1940 , and the vast majority were teachers $(60 \%$ were in elementary and secondary schools and $4 \%$ were teaching in colleges). Even to contemporary commentators, their choice of occupation was viewed as peculiar: "If it be asked

\footnotetext{
${ }^{18}$ The age group is determined by the demands of the most recent data.

${ }^{19}$ These figures are for women 45 to 54 years old. It should be emphasized that even women in this cohort who did not attend college also had a rather low rate of ever-marrying.
} 
why college women marry less than others, it may very safely be answered ... that it is not because they crave a more exciting and public life; for the majority of them are school-teachers (Shinn 1895, p. 947, emphasis in original). Of those 45 to 54 years old who had never had a birth but were in the ever-married group, $34.1 \%$ were in the labor force; of those who were currently married $28.4 \%$ were in the labor force. Even for the college graduate woman with no children, marriage was a decisive factor in her employment.

College men were likely to have been drawn from the same families as the college women in cohort I, but their demographic fates were unaltered by their college experiences. In $194010.2 \%$ of all college graduate white males 45 to 54 years old were never married which is one-third the rate for women. Of men in this age group with no college $11.4 \%$ were never married, slightly higher than the rate for college graduates. In 1950 just under $7 \%$ of all college graduate men, 45 to 54 years old, had never married, or one-quarter the rate for women. In 1960 the percentage for men was also $7 \%$ or one-third that for women, and in 1970 it was about $6 \%$ or one-half that for women. ${ }^{20}$ The percentage of college graduate men who married by the time they reached age 45 was virtually identical to, indeed somewhat higher than, that of men with no college. Thus the marriage rate of men was virtually unaffected by college, whereas that for women was reduced, at times substantially.

What accounts for the fact that $50 \%$ of female college graduates in cohort I either did not marry or did not have children by age 45 to 54 when the figure was $22 \%$ for women without college? Particularly since the percentage graduating from college was very low at the time, one cannot rule out the possibility that college women were a self-selected group who would have had the same demographic fate even had they not attended college. Colleges, like Bryn Mawr, were known to have attracted young women who had no intention of marrying and to have

\footnotetext{
${ }^{20}$ U.S. Bureau of the Census $(1953,1966,1972)$ and the 1940 PUMS.
} 
provided them with a "higher calling." But the percentage from the land-grant institutions who did not marry was also high. Thus the differences do not rest entirely on the type of college or the social backgrounds of the women.

The best evidence in support of the notion that college actually provided a "treatment effect" is that the percentage of female college graduates who never married (at each age) decreased substantially even when there was no increase in the percentage of women who were college graduates. The percentage of women who attended or graduated college, as can be seen in Figures 1 and 2, remained fairly constant for the cohorts born from 1905 to $1920 .{ }^{21}$ But the percentage who never married, as can be seen in Figure 6, began to fall sometime after the cohort born in 1890. Despite the stability in the percentage graduating from college, the percentage never marrying plummeted from around $25 \%$ to $10 \%$ for cohorts born from 1905 to 1920. If attending college involved self-selection, the underlying process would have had to change drastically to produce this result. Thus there is prima facie evidence that there was little or no self-selection because the demographic experiences of female college graduates changed by birth cohort before the increase in attendance and graduation rates.

Another way of establishing that self-selection cannot account for the high levels of nonmarriage among cohort $\mathrm{I}$ is to observe what happened in subsequent generations. Between cohort I and cohort III the percentage of the relevant female population who attended college for four years increased from $7 \%$ to $14 \%$ (see Appendix Table A1) and the proportion among them who never married plummeted from $30 \%$ to $8 \%$ (at age 55 to 64 years). I will construct a hypothetical case in which all never-married college-graduate women in cohort I are selfselected and show that the change over time rejects the hypothesis.

\footnotetext{
${ }^{21}$ I do not yet know what accounts for the sharp increase in college graduation rates, and to a lesser extent college attendance rates, with cohorts born around 1897. It is possible that the World War I military draft accounts for the rise.
} 
Consider the college graduate women in cohort I to consist of 100 of whom 30 self-select to go to college because they do not want to marry. That is, college in this hypothetical case provides no "treatment effect" regarding marriage. If we double the number of college graduate women to 200 we are duplicating what happened in the move from cohort I to cohort III. The 30 single women for whom college provides no "treatment" will remain in the group. As an extreme case, assume that of the additional 100 there is no woman who will eventually remain unmarried; that is, the process that generates non-marriage is not random. The percentage of women in cohort III who remain single should fall from $30 \%$ to $15 \%$. But it fell to $8 \%$-- half that amount. The 30 women in cohort I could not have been self-selected from a population in which the desire to remain single remained constant. There must have been another set of factors accounting for the change in the proportion of college women who ever married.

Other evidence in support of the claim that self-selection was not the primary factor in the low marriage rate among cohort I can be found in alumnae records. An extensive set of alumnae surveys from Radcliffe College reveals that the percentage never-marrying among Radcliffe graduates tracks the national average very closely from 1890 to the 1970 s. But the economic and social backgrounds of the Radcliffe graduates remained fairly constant. If anything, because the was an increase in the proportion of Radcliffe students drawn from private, as opposed to public, secondary schools from 1910 to 1960 , they may have come from more, rather than less, elite families. Yet their marriage rates increased. ${ }^{22}$

Why, then, did the first cohort of college women marry at low rates and why did the

${ }^{22}$ These findings come from a project using two extraordinary surveys of Radcliffe graduates: the Centennial Survey (covering graduating cohorts from 1910 to 1975) and that taken during the semicentennial in 1928 (covering graduating cohorts from around 1890). I will be using these surveys in future research on college women. The percentage graduating from public secondary schools was $67 \%$ for the 1910-1919 graduating cohort but $49.4 \%$ for the 1950-1959 graduating cohort. See Solomon (1985) for a discussion of the semi-centennial survey. 
rates begin to increase with subsequent cohorts? An important clue is found in what educated women, in particular educated married women, were allowed to do at the time. Educated women were, by and large, teachers, and, beginning sometime around the end of the nineteenth century, school districts adopted policies restricting the hiring of married women and firing single women who married in service. These "marriage bars" increased slowly to the 1920 s and then, with the necessity to ration jobs during the Great Depression, they escalated in the 1930s in teaching, office work, government jobs, and various other positions (Goldin 1990, 1991). Many of the college women who taught when married were employed by private schools or found public school positions in some of the nation's large cities that reversed their marriage bars earlier in the century or never had such policies. There was also considerable social opprobrium regarding the employment of married women, even those in white-collar jobs before the 1940s.

For many of the college-educated women of cohort I, their era left them little choice. They could marry or they could have a career in teaching, but they could not easily do both. Marriage bars in teaching were largely removed after 1941 when both the exigencies of the war and the, possibly related, spate of state supreme court rulings declared marriage bars to be "capricious and unjust" (see Goldin 1990, p. 170).

Even though the percentage of college women who never married by age 45 to 54 decreased to $19.1 \%$ by the cohort born around 1910 , it was $6.1 \%$ for those who were not college educated. Although it plummeted to $7.3 \%$ by the cohort born around 1940, it decreased to just $3.8 \%$ for those with no college education. College women were following a trend in nuptiality that was sweeping the nation, a trend apparent in Figure 7 for non-college women. The second factor, then, to have increased the marriage rates of college women was the general increase in marriage and family after the Great Depression. College women were enabled to have both family and job and were enticed to do so by a new norm that had, for a time, universal appeal. 


\section{Cohort III: Family then Job}

By cohort III, college women had joined a bandwagon. All Americans, independent of educational attainment, were marrying at their highest rates in the twentieth century (see Figure 7). And college women were not just increasing their marriage rates, they were also increasing their numbers in proportion to the female population. During the 20 -year expanse of this cohort, graduation and attendance rates doubled (see Appendix Table A1). Women followed the lead of men into college, but the increase of men was so rapid that by the end of the 1940 s men substantially outnumbered women. ${ }^{23}$ In 1925 there were as many female undergraduates as male undergraduates, and for the ten years preceding there had been more women than men undergraduates (see Figure 8). ${ }^{24}$ But by 1950 there were 2 men for every woman in college. Even after the peak in post-war enrollments, say in 1960, male undergraduates outnumbered female undergraduates by 1.5 to 1 . Because the statistics in Figure 8 are from contemporaneous data, whereas those in Figures 1 and 2 are for birth cohorts, they more accurately reflect the proportions of males and females in college during a particular year.

Family, not just marriage, took the country by storm in the post-World War II era, and college women were not left out of this trend either. Among the college women who did marry,

\footnotetext{
${ }^{23}$ It should be noted that World War II also affected women's presence in the academy because they were allowed to enroll in far greater numbers during the shortage of male students. Many universities, such as Harvard, changed their rules during World War II, allowing women to take classes previously reserved for men only.

${ }^{24}$ Attendance at both junior colleges and normal schools could inflate the statistics for women more than for men. Both were intended for less than a four-year period. As a percentage of total undergraduate enrollment by sex, junior (or two-year) colleges have been attended by men to the same degree as women. The same was not the case for normal schools, a teacher-training program that did not culminate in a degree. Women, to a far greater extent than men, attended normal schools and state teachers' colleges, although the latter were four-year institutions. The education statistics for the pre-1940s period, however, do not conveniently separate individuals who attended normal schools from those who attended state teachers' colleges. Data for 1929/30 indicate that among all female undergraduates in state teachers' college and normal schools only $20 \%$ were in normal schools. The same data also indicate that about $30 \%$ of all female undergraduates who began in teachers' colleges finished the four-year program and graduated (Office of Education, Biennial Survey of Education 1928/30).
} 
a far smaller percentage were not having children. About $10 \%$, or a third the level for the first cohort, did not have a baby by ages 35 to 44 in the cohort born from 1926 to 1935 . Thus for the second cohort, $17.5 \%$ were either not marrying, not having children, or both, compared with $50 \%$ for the previous cohort. ${ }^{25}$ College women had become part of the American mainstream in various ways. College was considerably more open to the masses, college women were marrying at a greater rate, and they were bearing far more children when married. But I emphasize that the timing of these changes is important to the argument and that the change in marriage and fertility rates preceded the increase in college attendance and graduation rates. Further, as noted above, the marriage and fertility increases were quantitatively larger than the increase in the proportion of women who graduated from college. Self-selection, with increasing enrollments, could not be the sole driving force in the changing demography of college women.

After World War II college became more accessible to and desired by Americans from most walks of life. The college enrollment of men soared in the 1950 s when they outnumbered women about two to one, as can be seen in Figure 8 . With the decline in the marriage age for all Americans, college became, de facto, an active marriage market in which the supply of husbands greatly outstripped the demand. In general, as the age at first marriage declines and that at leaving school increases, the probability of meeting one's spouse in school increases. Among the female college graduates in cohort III who eventually married, $57.2 \%$ did so before or within a year of college graduation. ${ }^{26}$ Marrying a college man -- and there was a large financial gain from doing so - was made far more likely through the route of college attendance.

Whether the direct, pecuniary return to college was greater than some appropriate

\footnotetext{
${ }^{25}$ Only $8.2 \%$ of the cohort born during $1926-35$ never married by age $55-64$. The $17.5 \%$ figure is: $8.2 \%$ (= \% never married) $+[91.8 \% \times 10.1 \%$ (= \% with no children among those ever-married, by age $35-44)]$.

${ }^{26}$ See Goldin (1992), table 2. The figure is computed from the 1960 PUMS by defining "marriage before or in year of school completion" as: (years of school attended +6 ) $\geq$ age at first marriage.
} 
alternative rate is relevant for all cohorts. Various factors make the question of particular importance for cohort III. When elites dominated college classes, the "country club" provided the preferred marriage market. But when "ordinary Joe" went to college, the only place for "ordinary Jane" to meet him was at college, and the campus took the place of the country club.

The direct pecuniary returns for the median female graduate probably fell short of the alternative rate of return. But the indirect pecuniary returns through the marriage market could have more than made up for the short-fall and may have been the initial impetus for the subsequent increase in the college attendance of women.

One can easily compute the returns to women's college education under a number of reasonable assumptions. The median female college graduate in the mid-1950s married in her year of graduation and, if she married, she worked for 4 years and then exited the labor force for about 8 years. ${ }^{27}$ She reentered the labor force, therefore, at about age 35 . A high school graduate, it will be assumed, also exited from the labor force after 4 years but remained out for 10 years or 2 more years than the college graduate. The ratio of the earnings of a college graduate woman to those of a high school graduate was about 1.3 when the college woman entered the labor market and increased to about 1.4 by mid-life for both of them. ${ }^{28}$ In nominal

${ }^{27}$ In a sample of about 700 female graduates of the class of $1957,42 \%$ married before or within 8 months of graduation (see Goldin 1992). Of those who were married by 1964, or seven years after graduation, the median woman worked until 1961 or for four years after graduation. In 1964 the median graduate had one 3-year old and an infant (or was probably expecting one). Among those without children, more than $80 \%$ were in the labor force. The addition of a child under 3-years old reduced participation to $26 \%$ and a 3 to 5 -year old reduced it to $35 \%$. There were too few women with 6 -year olds and over to observe when women, in this sample, began to reenter the labor market. I assume here that most reentered when their children began first grade. Thus they exited after 4 years and remained out for 8 years, or long enough for the youngest of the two to be 5 to 6-years old. My sense is that, for various reasons, this is an underestimate of the median time spent out and will, therefore, result in an overstatement of the rate of return.

${ }^{28}$ The annual starting income for college graduates in the class of 1957 was about $\$ 3800$ (1957 dollar), close to the figure from the 1960 PUMS for college graduate women, assuming an annual increase, in nominal terms, of about $2.5 \%$. The ratio of a college to a high school graduate's annual income was 1.3 , in the 1960 PUMS, for 25 to 29 year olds, but 1.4 for 44 to 49 year olds. 
amounts the college woman, at the moment of her graduation in 1960 , earned around $\$ 4000$ whereas the high school graduate of 1956 earned around $\$ 3000$. The direct expense for each of the four years of college was $\$ 837$ for public universities and $\$ 1552$ for private universities. ${ }^{29}$ Both the high school and college graduate women are assumed to work continuously after they reenter the work force until age 60 , and their reentry earnings are taken to be those at the time of exit. Under these assumptions, the internal rate of return to the four years of college investment was between 4 and $6 \%{ }^{30}$ The internal rate of return to college for men at that time exceeded $10 \%$, or more than double that for women (Freeman 1977). Even though the return to college for men and women - given by the ratio of wages earned by a college graduate to those of a high school graduate -- was comparable, the internal rate of return for women was half that for men because of briefer employment.

But the simple calculation does not consider that college affected a woman's future resources through the man she married, what I will term the "indirect" return to college. In 1960 the probability a woman 30 to 39 years old would marry a college graduate was vastly increased by her graduating from college. Almost two-thirds of all college-graduate women (30 and 39 years and married) married a college graduate and more than one-third of those who attended college, but did not graduate from a four-year school, did. Only $10 \%$ of the high school graduate women married a college graduate (see Goldin 1992, table 3).

\footnotetext{
${ }^{29}$ Figures are for tuition, room, and (7-day) board (U.S. Department of Health, Education, and Welfare, Office of Education 1960).

${ }^{30}$ The calculation solves for $\mathrm{r}$ in the standard equation: $\Sigma C_{\mathrm{t}} /(1+r)^{\mathrm{t}}+\sum \mathrm{Y}_{\mathrm{t}}^{\mathrm{c}} /(1+\mathrm{r})^{\mathrm{t}}=\Sigma \mathrm{Y}_{\mathrm{th}} \mathrm{t} /(1+\mathrm{r})^{\mathrm{t}}$,

where $\mathrm{C}=$ direct costs of college, $\mathrm{Y}^{\mathfrak{c}}=$ income of a college educated woman, $\mathrm{Y}^{\text {hs }}=$ income of a high-school educated woman. A woman is assumed to graduate from high school at age 18, work until she exits from the labor force (presumably to raise a family) at age 22, reenter the labor force at age 32 , and retire at age 60 . If she, instead, graduates from college, she works from 22 to 26 , exits at 26 , reenters at 34 , and retires at 60 . Wages for both high school and college graduate women rise with job experience so that the ratio begins at 1.3 but rises to 1.4 by mid-life.
} 
Not only did college-educated women face a much higher probability of marrying a college man, they also married men with higher incomes within each educational level. Further, among the women who attended college and married college men, those who married during college or immediately following graduation nabbed husbands with higher earnings. The early birds got the bigger worms. On the negative side, however, college women still had a somewhat lower probability of ever getting married, although it was considerably higher than for the previous cohorts. ${ }^{31}$

The indirect computation is quite simple and uses the 1960 PUMS. A standard log earnings equation is estimated for the husbands, to which are added variables concerning wife's education and the timing of their marriage in relation to her education (see Goldin 1992, table 4). The thought experiment involves taking a high school graduate woman in the 1950s, giving her four years of college, and then observing her husband's income in 1960 when she was between 30 and 39 years. The total impact is to increase her husband's income by almost $40 \%{ }^{32}$ The largest component $(66.5 \%)$ comes from altering the probability she will marry a man at particular educational levels. The likelihood that she will marry a man who attended or graduated from college increases, whereas the likelihood that she will marry at all other levels decreases. This change, then, increases husbands' income by $27 \%$.

But increasing her education results in another effect. The college graduate woman married the higher income-earning man, given his education. This factor accounts for $22.5 \%$ of

${ }^{31}$ For women 30 to 39 years old in $1960,6 \%$ of those who graduated high school but did not attend college had never married. Of those who attended college, but did not complete four years, $7.1 \%$ had not married. Of those who graduated college $15.1 \%$ were still in the never-married group in 1960, although by the 1980 s only $8 \%$ of this group had never married.

${ }^{32}$ The total change in (the log of income from is 0.334 and $\exp (0.334)=1.3965$ or about 40 percent. The 0.334 figure is almost identical to the difference in the coefficients on wife's education (college minus high school graduate $=0.324$ ) in a regression on their husband's income, not including any other covariates. 
the total, or a $9 \%$ gain in husband's income for the college graduate woman over that of the high school graduate. Because almost $80 \%$ of all college graduate women married a man who attended some college, the effect can be thought of as part of the gains from the college marriage market. Another possible interpretation is that women with more education were better able to assist their husbands and thereby directly enhanced their income. ${ }^{33}$ Finally, a third effect involves the fact that marrying early, either in college or upon graduation, also increases one's earnings. The "early bird" effect adds the remaining $11 \%$ of the total or about a $4 \%$ gain in income for the college graduate woman. Overall, therefore, the thought-experiment of giving a high school graduate woman a college education in the 1950s increased her income through the marriage market by $40 \% .^{34}$

Following the logic of treating the indirect gain as one does the direct gains from education and assuming the woman marries and does not divorce, the total returns to her education are now greatly augmented and, under reasonable assumptions, double. The total

${ }^{33}$ Because the factor "married in college" is not of importance for the 50 to 59 year old group (see Goldin 1992), the marriage market hypothesis seems more compelling.

Benham (1974) estimates a similar equation, using the 1960 PUMS, but with a different purpose. He interprets the positive coefficient on women's education in the male earnings equation as indicating the greater productivity of more educated women in the home and their impact on their husband's earnings. To distinguish between the marriage market and productivity hypotheses, Benham includes the wife's age at marriage in the husband's earnings equation, together with their respective levels of education. Women who marry later given their level of education have a higher probability of having finished their education after marriage. Under the selectivity hypothesis, husband's earnings should be unaffected by post-marriage education whereas it might be affected under the productivity hypothesis. Benham finds a negative coefficient on the age at marriage and interprets it as not supporting the selectivity hypothesis. But women who marry later, given their level of education, were less likely to have taken advantage of the marriage market in college or high school. That is, Benham's variable is picking up part of the "early bird" effect.

More importantly, my way of separating the productivity hypothesis from that concerning the marriage market is to note that the productivity hypothesis can take effect only within educational groups. The largest single effect on a woman's income from going to college was from marrying the collegeeducated man. That effect cannot be due to her enhancing his productivity but must, instead, be sought in a marriage market model.

${ }^{34}$ How one treats this income depends on various assumptions concerning, how long she remains married and whether, should she divorce, she receives alimony in proportion to her husband's income. 
return to college for the second cohort, rather than being in the range of 4 to $6 \%$, is now closer to 10 or $11 \%$. Thus the full return to women's college education in the 1950 s is increased from a value that is somewhat less than the real return to assets to one that is more in line with the returns to college education for men. Families, therefore, should have been willing to send a daughter to college if they viewed her marriage prospects as being enhanced by the experience. Thus it would not be surprising if many families refused to pay for their daughter's education if they thought she would simply marry the "boy next door."

The majority of those in cohort III, like most in cohort I, prepared to be teachers. The percentage who were teachers in 1960 decreased slightly from that of the previous group, but was still between 50 and 60 percent. And the percentage who taught at some time in their lives must have been considerably greater. The employment rates of married women in cohort III were not much higher than were those of the previous cohort when they were young $(29.6 \%$ versus $25.3 \%$ ) and thus did not greatly exceed those of women who did not attend college $(29.6 \%$ versus $26.7 \%){ }^{35}$ But their employment rates greatly exceeded those of women who did not attend college when both groups were older. That is, college women who married and had children were now having family and employment serially - first family and then, when their children were teenagers, employment.

To recap, cohort III had substantially higher marriage and fertility rates than those of cohort I, were in the labor force considerably more when older but not much more when younger, and were teachers to almost the same degree. The women of cohort III benefited by the substantial decrease in barriers to their employment. Before the 1940 s the vast majority of school districts and many employers of office workers had "marriage bars" -- stated policies that

\footnotetext{
${ }^{35}$ The $25.3 \%$ figure is for those graduating around 1928 to 1937 , whereas the $29.6 \%$ figure is for those graduating around 1948 to 1957.
} 
married women would not be hired and that single women would be fired upon marriage (see Goldin 1990, 1991). Added to the marriage bars were reinforcing and pervasive norms restricting the ability of married women to work for pay. Of additional importance is that the number of men entering college increased substantially in the 1940s and 1950s. Finally, all Americans were marrying earlier and having more children, and these changes affected the college educated as well. The three changes were reinforcing. College women no longer had to treat marriage and employment as alternatives in life, and college was no longer just a place to learn for it was, de facto, transformed into a place to meet one's spouse.

But as this generation aged it became less content with its small victories, and successive generations of college women launched a campaign for more equality and finally for real equality. Cohort III included the women aroused by The Feminine Mystique (1963) in which Betty Friedan described the experiences of her own generation who graduated college in the 1940s. Feminism sprung from this group who knew they were as able as their male friends in college but who encountered a world outside college that was not ready for them.

\section{Cohort IV: Career then Family}

Cohort IV -- graduating from 1966 to 1979 and born 1944 to 1957 -- was the first to enter the labor force in the era of modern feminism. I characterize it as having desired "career then family" because it has delayed marriage and children while it has pursued career. But in consequence, it has experienced a high rate of childlessness. I will also show that its success rate in the employment arena has not been stellar. In the popular press it is often portrayed as trying to combine career with family, juggling both with little spousal help at home.

The Current Population Reports, P-20 series reveals that among those with four or more 
years of college, $27.4 \%$ of this cohort have not yet had a first birth by $1990 .^{36}$ And among those with more than four years of college, $33.3 \%$ have not. These figures, although not as extreme as those for cohort I, are higher than for any cohort since, and the proportion of women graduating college is almost 10 times what it was in 1910. These figures do not look good for the "family and career" route. But in comparison with previous cohorts, a far higher proportion of cohort IV has been employed since college graduation. Even though many have not yet had a first birth, a substantial proportion of the cohort could be "having it all."

Longitudinal data are needed to gauge the success of the group at attaining career goals. The N.L.S. Young Women is precisely the cohort of interest and at last interview, in 1991, it was between 37 and 47 years old. The survey began in 1968 with about 5,000 participants, but through attrition was been whittled down to about 2,400 in 1988 when the group was between 34 and 44 years old. The sample in 1988 of white women who earned a B.A. degree was 600 and 646 for those with four or more years of college. Yet, amazingly enough, its demographic features are very similar to those in the relevant C.P.S. group.

Figures 4 and 5, giving the percentage of college women having no births by age 35 to 44, contain a demarcated area for the N.L.S. cohort and data points for the N.L.S. cohort in 1988. Among white, N.L.S. ever-married women with four or more years of college and 35 to 44 years old in $1988,19 \%$ had not yet had a first birth (Figure 4); the figure in the relevant C.P.S. is $18.9 \%$. For all marital groups the N.L.S. figure is $29.1 \%$ (Figure 5) whereas that in the C.P.S. is $28.2 \%$. Similarly, for the data on percentage never-married by ages 25 to 34 years and 35 to 44 years,

\footnotetext{
${ }^{36}$ The figure for those with a B.A. degree is $26.9 \%$ in 1992, although the educational categories change from 1990 to 1992. There is a decrease in those without a first birth moving from the measure $\geq 4$ years of college to having a B.A. degree that can be duplicated, to some extent, in the N.L.S. data.
} 
Figure 6 shows the close agreement between the N.L.S. data and that in the 1980 census. ${ }^{37}$

Gauging whether a woman has achieved a "career" is considerably less objective than determining whether she had a first birth. Any measure will be arbitrary. Because careers are generally assessed against a male standard, I begin by defining a "career" as attaining an earnings path that some group of men has achieved. I use the earnings of women in their late thirties and early forties, when both family and schooling investments were generally complete. The standard will be the man at the 25th percentile. For women to achieve a "career" will not even require that they reach the median of male hourly earnings in any one year.

I first define a "career" for the N.L.S. women with four or more years of college to be an earnings path for a series of years (say 1987 and 1988) during which their hourly earnings exceeds that of the 25 th percentile male (in the relevant C.P.S.) also with four or more years of college. I restrict the N.L.S. sample to women who are represented for all the years under consideration (see also notes to Tables 4 and 5 for other exclusions).

Mean and median hourly earnings for women with four or more years of college are fairly similar in the C.P.S. and N.L.S. for the 1980 to 1988 period, even though neither sample has been weighted in any comparable manner (see Table 4). ${ }^{38}$ Further, it is interesting to note that the medians for women are in the range of the 25th percentile in the male distribution.

The results on "career" are presented in Table 5 in two manners. The first includes only those with positive hourly earnings in each of the years considered, that is only those in the labor force and not self-employed. The second accounts for women who were not in the labor

\footnotetext{
${ }^{37}$ I use $\geq 16$ years of schooling, as the definition of college graduate, when making comparisons with the C.P.S. but a B.A. degree when not. When the P-20 series of the Current Population Reports refers to 35 to 44 year olds, I drop the youngest age in the N.L.S. for comparison. Consistency is attempted with any data set in making comparisons with the N.L.S.

${ }^{38}$ The N.L.S. calculated hourly earnings differently in 1991 than before (see Table 4). For those reasons, I do not use 1991 in the calculation of "career."
} 
force in any one or all of the years. Given the definition of a "career," $43 \%$ of all (white) women with 4 years or more of college employed in both 1987 and 1988 are above the mark. Selfemployed women are excluded from both the numerator and denominator, but are included in another measure of "career." ${ }^{\prime 39}$ The "career" figure is $35 \%$ for women who had at least one child and $56 \%$ for those who did not. Restricting the definition to attaining the same cutoff for 1985,1987 , and 1988 gives $30 \%$ for women with children and $47 \%$ for those without.

The percentages just given are computed for women who were employed in each of the years considered. But some of the women were not in the labor force in one or all of the years considered. Panel B of Table 5 adjusts for the labor force participation rate (of the non-self employed). Using the two-year definition gives $24 \%$ of the women with children and $54 \%$ of those without. Employing the three-year definition gives $18 \%$ of the women who had children and $45 \%$ of those who had none..$^{40}$ Very similar estimates are obtained by using income, rather than the hourly earnings, and the income measure enables the inclusion of the self-employed as well as others whose hourly earnings are omitted.

The percentage of these women who attained family and career can be seen in Table 6 for four definitions of career: the 2-year and 3-year measures for both the hourly wage and annual income data. ${ }^{41}$ The conclusions are not substantially affected by the choice of earnings variable and I will make reference only to the hourly earnings results. Using the 3-year definition, only $13 \%$ of the group attained both "family and career." Another $13 \%$ had career but no family, and $74 \%$ did not attain career of whom $78 \%$ had family. Using the 2 -year

\footnotetext{
${ }^{39}$ The self-employed are also excluded from the hourly earnings figures in the C.P.S.

${ }^{40}$ Note that the three-year definition really spans four years because of the absence of data for 1986.

${ }^{41}$ The income measure is almost exactly the same as the hourly wage measure. It uses the hourly wage of the male at the 25th percentile multiplied by 2,000 hours. The group of women included expands, in part, because it includes the self-employed.
} 
definition, $17 \%$ attained both "family and career," and another $16 \%$ has career but no family. For every woman who attained family and career there was another woman who attained career but had no family, using any of the definitions.

The definitions of career just employed may be subject to the criticism that they adopt a male income standard. If career is meant to proxy success as judged by the individual, a personal standard would be more appropriate. But the intent is not to discern whether women found contentment in their paid work. Rather, it is to assess whether those observing them judge that they attained careers. Another potential criticism is that life continues after age 40 and careers, for many, begin in mid-life. Once again, the issue here is whether cohort IV has achieved "family and career" by mid-life, an oft-stated goal of many in cohorts IV and V.

Other definitions can be devised that do not use a male income standard. Consider, for example, a definition of career based on employment and full-time commitment, with no income or hourly wage cutoff. More concretely, consider a woman to have a career if she is in the labor force for each of three years $(1985,1987$, and 1988) during which time she is generally a full-time worker (as an employee or self-employed). ${ }^{42}$ Among those in the sample who had at least one child, $31 \%$ had careers using this definition, and among those who did not have a child $67 \%$ had careers. But only $22 \%$ of the total group had "family and career" using this definition. The percentage is higher than that obtained using the income or hourly wage cutoff, but it still implies that one college graduate woman in 4.5 attained "family and career" by age 40 .

Defining career as (usually) full-time, although not necessarily year-round, employment

\footnotetext{
${ }^{42}$ The criteria are applied to white women, with highest grade completed equal to 16 or more years. The women must have been in the labor force in 1985, 1987, and 1988 (using the Current Population Survey definition of labor force participation), and their usual hours worked in the preceding year must have exceeded 39. Because hours and labor force participation apply to different years, there are some cases of missing values for usual hours worked for women considered in the labor force. These cases have been coded as "career" as long as usual hours in other years exceeds 39 or is missing. This decision rule results in an upper bound estimate of the percentage with "career."
} 
during each of three years, is not what is generally meant by career. More than $40 \%$ of the women deemed to have a career using this definition did not, in 1985 , attain the income level of a college graduate man at the 25th percentile of the male distribution; just $53 \%$ of these "career" women attained the income level of the college graduate man at the 25th percentile of the male distribution in both 1985 and $1987 .{ }^{43}$ Why the figure for "family and career" is low even when lenient criteria are used can be understood by a decomposition. First is the fact that $28 \%$ of the women in the group did not have children, implying that the percentage with "family and career" cannot exceed $72 \%$ using any standard for career. Further, among those who had children, $46 \%$ were in the labor force for all three years $(1985,1987$, and 1988). The full-time commitment criterion brings the final figure down to $22 \%$.

One may wonder what percentage of men would pass the "career" standard imposed here. The N.L.S. Young Men survey was terminated in 1983 due to attrition but a substitute can be found in the P.S.I.D. (see Moffitt and Gottschalk 1993). ${ }^{44}$ The probability a man above the 20th percentile remained there for another year was $92 \%$; the probability he would stay for two years was $85 \%$; and $78 \%$ remained for four years. If the same probabilities held for the man above the 25th percentile (and held for college men to the same degree as for all men), $64 \%$ of men would have been above the mark using the two-year definition, whereas $43 \%$ of all college women were in the N.L.S.

The most generous interpretation of the data is that between one-fifth and one-quarter of all college graduate women with children attained career as they neared mid-life. And about one-half of the women without children have achieved career. But because almost $30 \%$ of the

\footnotetext{
${ }^{43}$ See the note to Table 6 for the procedure used to obtain the income at the 25 th percentile of the male distribution.

${ }^{44}$ The Moffitt and Gottschalk (1993) data are not given by educational group. I am using the transition matrix for the entire sample. In addition, they give quintiles not quartiles.
} 
cohort has not yet had its first birth, between $17 \%(0.712 \times 24 \%)$ and $13 \%(0.712 \times 18 \%)$ of the cohort have realized the goal of "family and career."

It is difficult to say what factors encouraged and enabled the women in this cohort to attain "family and career." Slightly more of the career than the non-career women expressed a desire when they were 15 to 25 years old for paid employment when 35 -years old $(60.3 \%$ versus $56.7 \%$ in 1969). But most of the difference comes from the group who never had children among those attaining career $(63.5 \%$ versus $57.1 \%) .{ }^{45}$ That is, those eventually attaining career and no family were more apt to have expressed an early desire for paid employment.

Divorce was considerably more common among the ever-married women who attained career than among those who did not (37.5\% versus $23.0 \%$ using hourly earnings; $43.9 \%$ versus $22.5 \%$ using income). And conditioning on having children does not change the difference much ( $33.3 \%$ versus $16.9 \%$ using hourly earnings; $37.1 \%$ versus $18.1 \%$ using income). It was career, not children, that somehow affected divorce, or vice versa. College graduate women with both family and career had a divorce rate that was $20 \%$ to $30 \%$ higher than average for the entire group of college women. ${ }^{46}$ Not only was divorce more common, marriage was less frequent among college women who would eventually attain career. Among those who achieved career, $76 \%$ married by 1988 , whereas among those who did not attain career $87 \%$ married. ${ }^{47}$ Thus in 1985 only $53 \%$ of the career group was currently married whereas $79 \%$ of the non-career group was. I would like to emphasize, however, that the determination of "family and career" does not require that the college women was currently married nor that she had ever married.

\footnotetext{
${ }^{45}$ These data use the 3-year, hourly-eamings definition of career. See Table 5.

${ }^{46}$ I have conditioned the entire group on remaining in the sample in 1987. A range is given for the hourly and annual income measures using the 3-year definition.

${ }^{47}$ The data throughout this section use the 3-year hourly wage measure of career describe above and given in Tables 5 and 6.
} 
Women with careers, not surprisingly, had more years of education than the average college women $(64 \%$ of those with careers had more than 16 years versus $39 \%$ of those without careers). But there is no clear separation between those who attained their career with children and without $(59 \%$ of those with children had more than 16 years of schooling whereas $68 \%$ of those without children did). The N.L.S., despite its richness, does not hold the answer to the question in the minds of many college women today: what is the key to "family and career"? There are no obvious early differences and those that develop later in life, for example with regard to the timing of marriage and children, may be correlated with unobservable differences across individuals.

When today's young women look to cohort IV for guidance, it is clear why they express considerable frustration. Only $17 \%$ of the college graduate women in that cohort have achieved both "family and career" using the two-year definition and just $13 \%$ have using the three-year definition. ${ }^{48}$ Further, these definitions use a cutoff point of just the 25 th percentile of men. Looking on the bright side, however, one might consider these numbers to be non-trivial fractions of the cohort. And not only are they non-trivial, they are probably much higher than achieved by cohort III. That is, cohort IV is probably the first in U.S. history to contain even a small group who managed to reach mid-life with both family and career and is thus the only cohort that could provide a role-model for cohort V. But the fraction is sufficiently small that young women today have judged cohort IV to have failed at "having it all."

But are college women today judging the success or failure of cohort IV by their own standards, not those of cohort IV which may be more content with one or the other? The N.L.S. surveyed its participants concerning the desire for future births. Beginning in 1978 the question

\footnotetext{
${ }^{48}$ The $17 \%$ and $13 \%$ figures are derived from the underlying data but could be obtained by multiplying the percentage of women attaining careers who have had a first birth by the fraction having a first birth.
} 
was asked of all women, rather than just those who were ever-married. Among those who remained in the sample to 1991 and who did not have a first birth by 1991, 48.4\% desired one in 1978. For those in the group who were 24 to 29 years old in $1978,62.9 \%$ did. If the older group had been similarly inclined when they were 24 to 29 years old, a considerable fraction $(19 \%=63 \% \times 30 \%$ with no births by 1991$)$ of the entire cohort were disappointed with the "family" outcome. That is, somewhat more were disappointed with not having children as eventually achieved the "family and career" outcome.

\section{Summary and Conclusions}

The demographic and labor force experiences of college women changed considerably across the past century. In the first cohort of college women studied (graduating c.1910), 50\% either never married or never had a first birth. But by the third cohort (graduating c.1955), college graduate women were marrying and having children at rates that were high both by absolute standards and relative to other women their age. Cohort IV (graduating c.1972) is the most recent to have nearly completed its fertility history and rates of childlessness appear to have climbed once again, although they are far lower than for cohort I. Yet among women in this cohort who attained "career" status, using my definitions, nearly 50\% were childless by age 37 to 47 . "Career" still entails large costs.

I have emphasized altered social constraints surrounding women's paid employment as generating many of the changes across the cohorts. There is at least one important complication. College women, themselves, fought for many of these changes. Around the turn of this century a small fraction of men and women attended and graduated college. That for men climbed considerably just after World War II when college men outnumbered women by about 2 to 1 . Sometime during the 1940 s women realized that they could have family and job -- albeit serially 
timed, and that college could enable and enhance both. Although the direct returns to college for women probably did not justify their increased enrollments, the heightened indirect returns through the marriage market did. Thus some portion of the increase in college attendance and graduation rates of the women in cohort III was due to the simple fact that they followed men into college. By today's standards, that is not a kind characterization. But, paradoxically, profound social change was set in motion by cohort III, women who, by and large, entered college with the least motivation for academically-serious studies and whose "Mrs." degrees were worth nearly half of the total returns from their B.A.s.

Cohort IV was the recipient of cohort III's legacy: considerably loosened constraints in education and in the labor market. But, as they reach mid-life perhaps one-sixth have achieved the elusive goal of "family and career." Is it no wonder that today's college women assert they have few role models? 


\section{References}

Benham, Lee. 1974. "Benefits of Women's Education within Marriage." Lournal of Political Economy 82 (2, part II): S57-S72.

Cookingham, Mary E. 1984. “Bluestockings, Spinsters and Pedagogues: Women College Graduates, 1865-1910." Population Studies 38: 349-64.

Freeman, Richard B. 1977. The Overeducated American. New York: Academic Press.

Friedan Betty. 1963. The Feminine Mystique. New York: Norton.

Goldin, Claudia. 1990. Understanding the Gender Gap: An Economic History of American Women. New York: Oxford University Press.

--_.-1991. "Marriage Bars: Discrimination Against Married Women Workers, 1920 to 1950." In H. Rosovsky, D. Landes, P. Higgonet, eds., Favorites of Fortune: Technology, Growth, and Economic Development since the Industrial Revolution. Cambridge, MA: Harvard University Press.

1992. "The Meaning of College in the Lives of American Women: The Past Hundred Years," National Bureau of Economic Research Working Paper No. 4099 (June).

Moffitt, Robert, and Peter Gottschalk. 1993. "Trends in the Covariance Structure of Earnings in the U.S.: 1969-1987," unpublished paper (March).

Newcomer, Mabel. 1959. A Century of Higher Education for American Women. New York: Harper and Brothers Publishers.

Shinn, Millicent Washburn. 1895. "The Marriage Rate of College Women." The Century Magazine 50 (October): 946-48.

Solomon, Barbara Miller. 1985. In the Company of Educated Women. New Haven: Yale University Press.

U.S. Bureau of the Census. 1953. U.S. Census of Population: 1950. Vol. IV, Special Reports, Part 5, Chapter B, Education. Washington, DC: U.S. Government Printing Office.

-1955. U.S. Census of Population: 1950. Vol. IV, Special Reports, Part 5, Chapter C, Fertility. Washington, DC: U.S. Government Printing Office.

--1964. U.S. Census of Population: 1960. Subject Reports. Women by Number of Children Ever Born. Final Report PC(2)-3A. Washington, DC: U.S. Government Printing Office.

1966. U.S. Census of Population: 1960. Subject Reports. Age at First Marriage. Final Report PC(2)-4. Washington, DC: U.S. Government Printing Office.

1972. Census of Population: 1970. Marital Status. Final Report PC(2)-4C. Washington, DC: U.S. Government Printing Office. 
1973. Census of Population: 1970. Women by Number of Children Ever Born. Final Report PC(2)-3A. Washington, DC: U.S. Government Printing Office.

----. 1975. Historical Statistics of the United States from Colonial Times to the Present. Washington, DC: U.S. Government Printing Office.

-.-1 1985. Census of Population: 1980. Subject Reports. Marital Characteristics. Final Report PC80-2-4C. Washington, DC: U.S. Government Printing Office.

1991. Current Population Reports, Series P-20, No. 454, Fertility of American Women: June 1990. Washington, DC: U.S. Government Printing Office.

various years. Current Population Reports, Series P-20, various numbers, Fertility of American Women. Washington, DC: U.S. Government Printing Office.

U.S. Bureau of Education. various years. Biennial Survey of Education. Washington, DC: U.S. Government Printing Office.

U.S. Department of Education. 1991. Digest of Educational Statistics, 1990. February. Washington, DC: U.S. Government Printing Office.

------. various years. Biennial Survey of Education. Washington, DC: U.S. Government Printing Office.

U.S. Department of Health, Education, and Welfare, Office of Education. 1960. Higher Education Planning and Management Data, $1959-60$, by W. R. Bokelman. Circular No. 614 . Washington, DC: Government Printing Office.

-.-.- various years, OFE. Opening (Fall) Enrollment in Higher Education. Washington, DC: U.S. Government Printing Office.

various years, Digest. Digest of Education Statistics. Washington, DC: U.S. Government Printing Office.

Van Kleeck, Mary. 1918. "A Census of College Women." Journal of the Association of Collegiate Alumnae XI (9): 557-91.

Woody, Thomas. 1929. A History of Women's Education in the United States. Vol. 2. New York: The Science Press. 
Figure 1

Percentage of White Males and Females

Attending College, by Birth Cohort

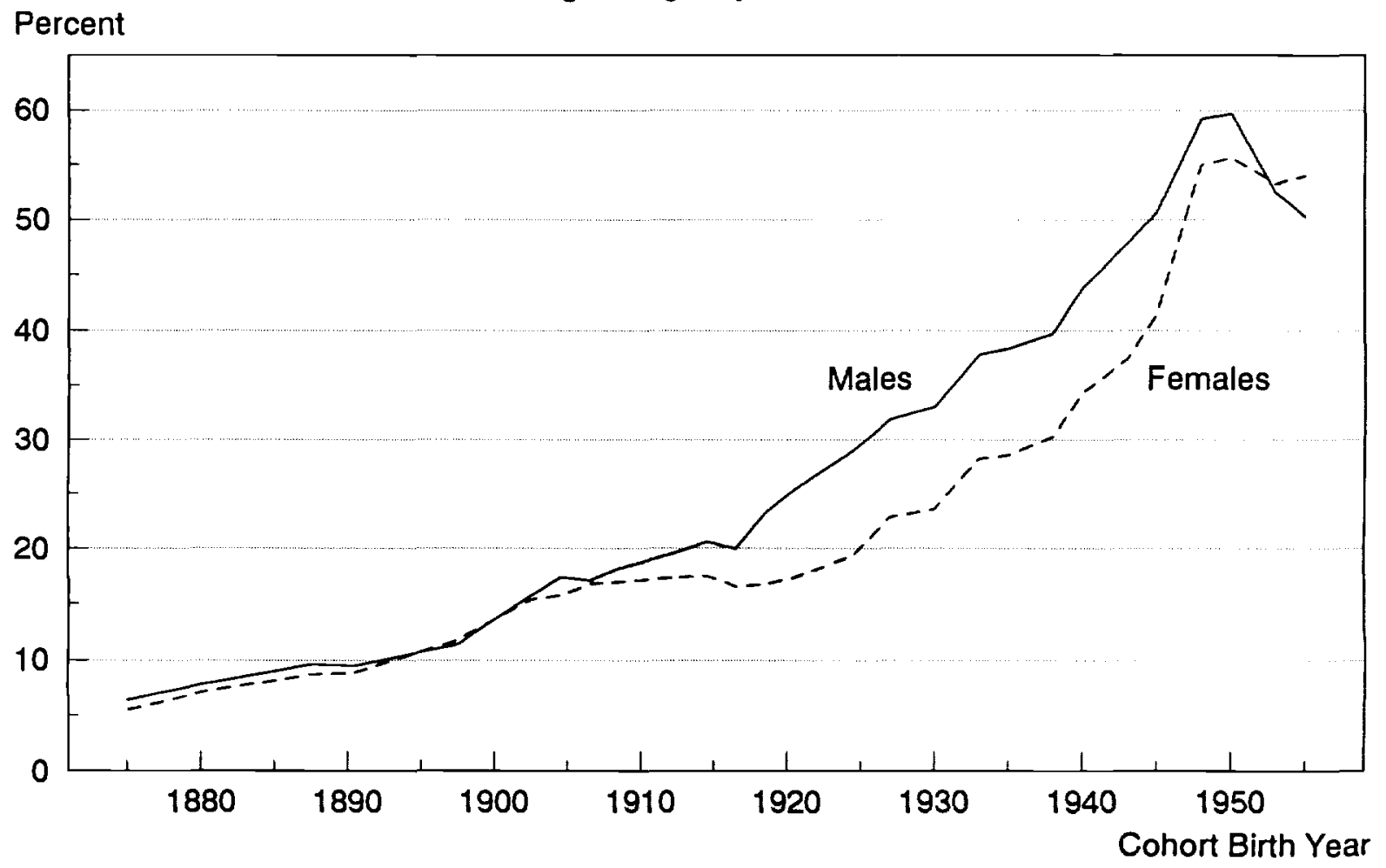

Sources: U.S. Bureau of the Census, Current Pooulmion Reports, P-20 series, "Educational Attainment in the United States," various dates. See also Appendix Table A1.

Notes: In virtually all cases only the responses of individuals 45 to 54 or 55 to 64 years old were used. For cohorts born since 1945 projections were made to 1995 or 1997 on the basis of changes for the preceding cohort that was 35-39 (30-34) years in 1977 and 45-49 (40-44) years in 1987. 
Figure 2

Percentage of White Males and Females

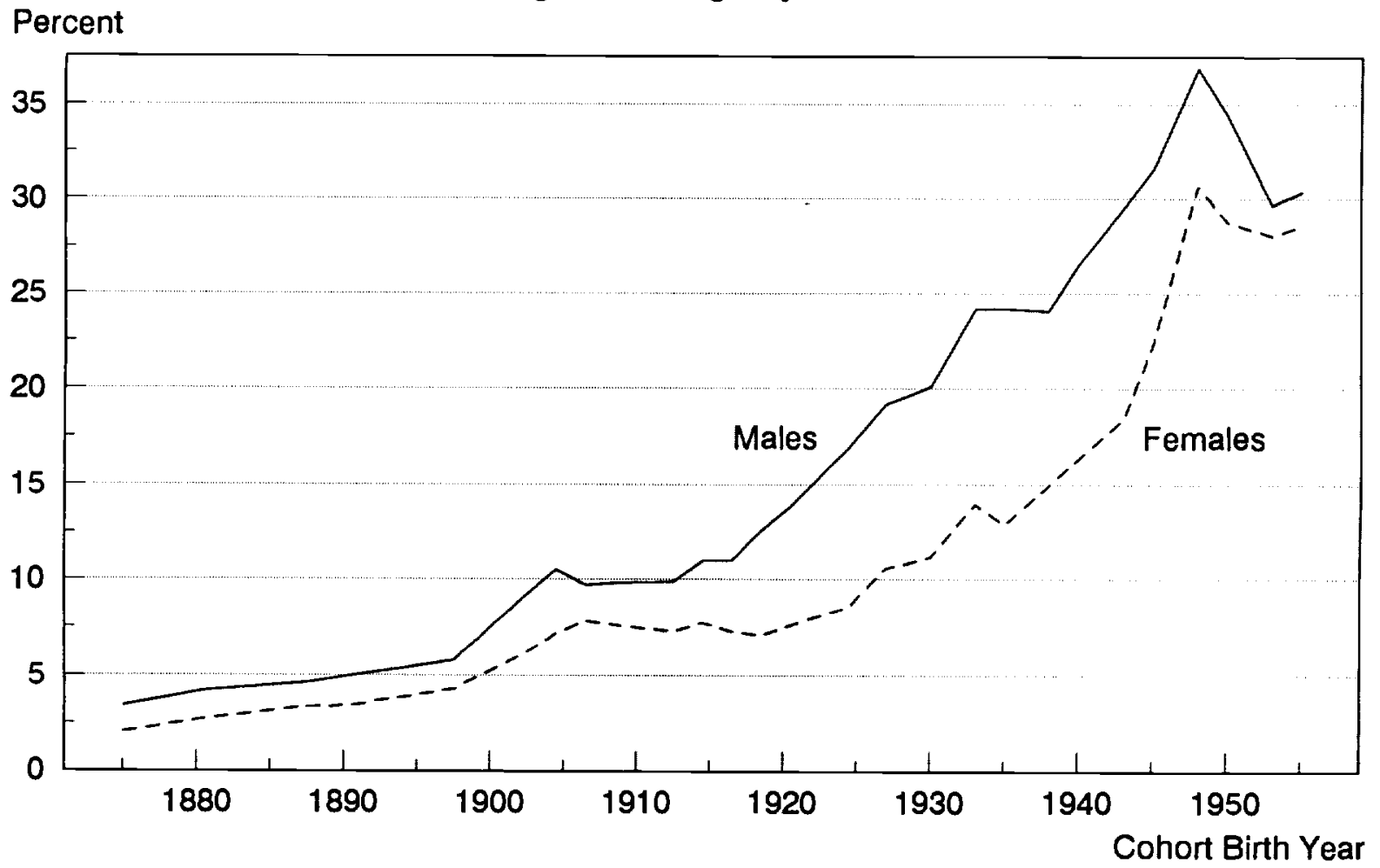

Sources: U.S. Bureau of the Census, Current Poputhtion Reports, P-20 series, "Educational Attainment in the United States," various dates. See also Appendix Table A1.

Notes: In virtually all cases only the responses of individuals 45 to 54 or 55 to 64 years old were used. For cohorts born since 1945 projections were made to 1995 or 1997 on the basis of changes for the preceding cohort that was 35-39 (30-34) years in 1977 and 45-49 (40-44) years in 1987. 
Figure 3: A Framework for Understanding Family and Career Choice

\section{Panel A: Three-period Budget Constraint}

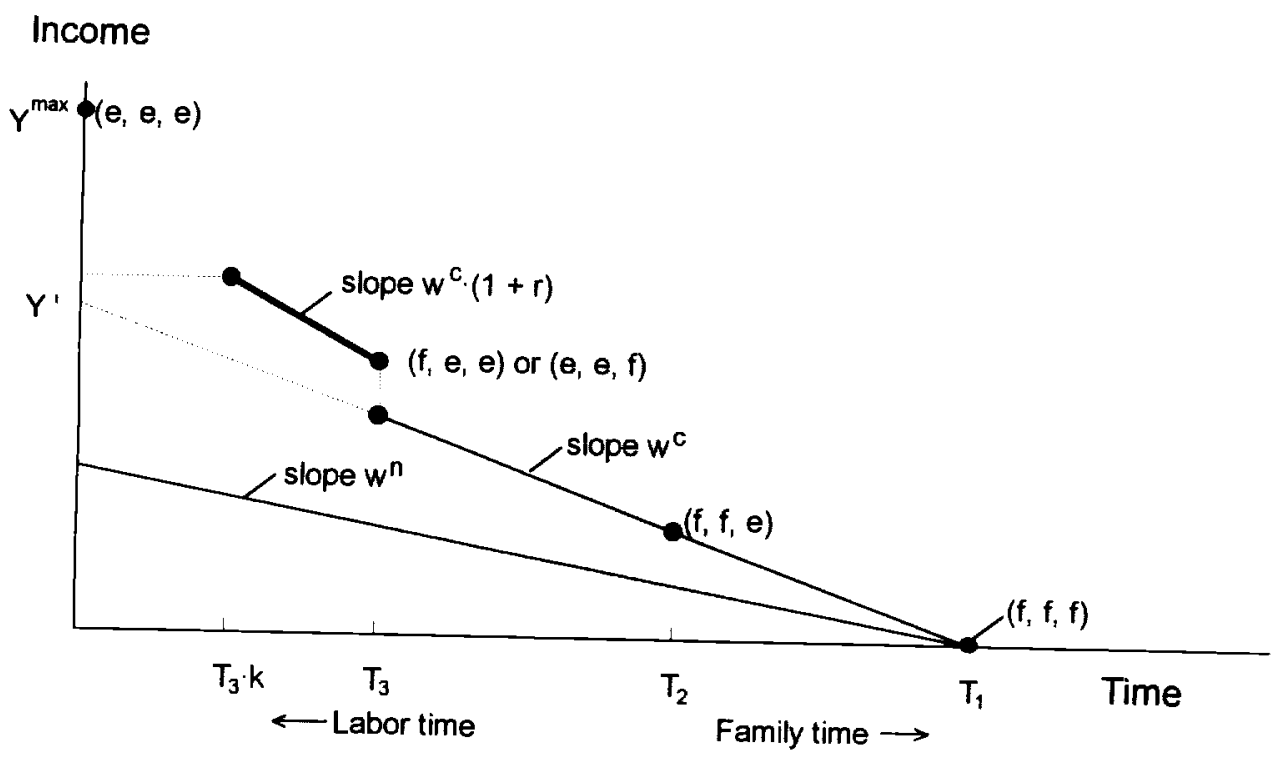

Panel B: Career and Family Choice

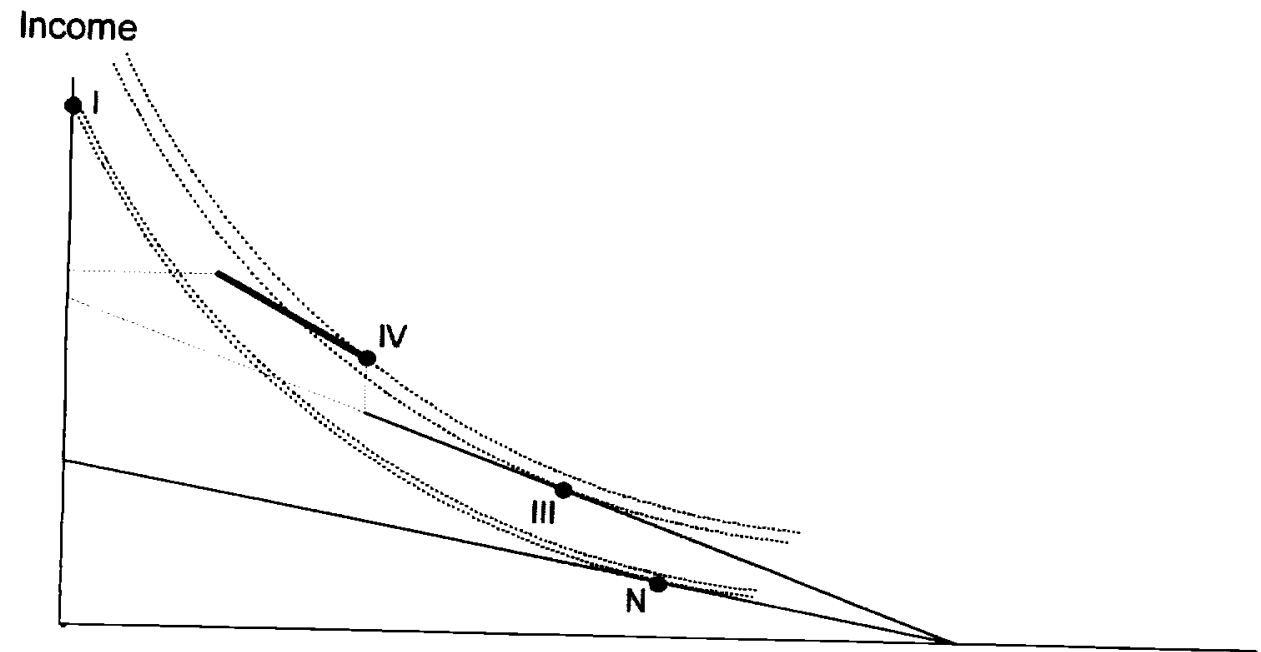


Figure 4

Percentage of Ever-Married White Women

with No Births by Ages 35-44

$\%$ with No Births by Age 35-44

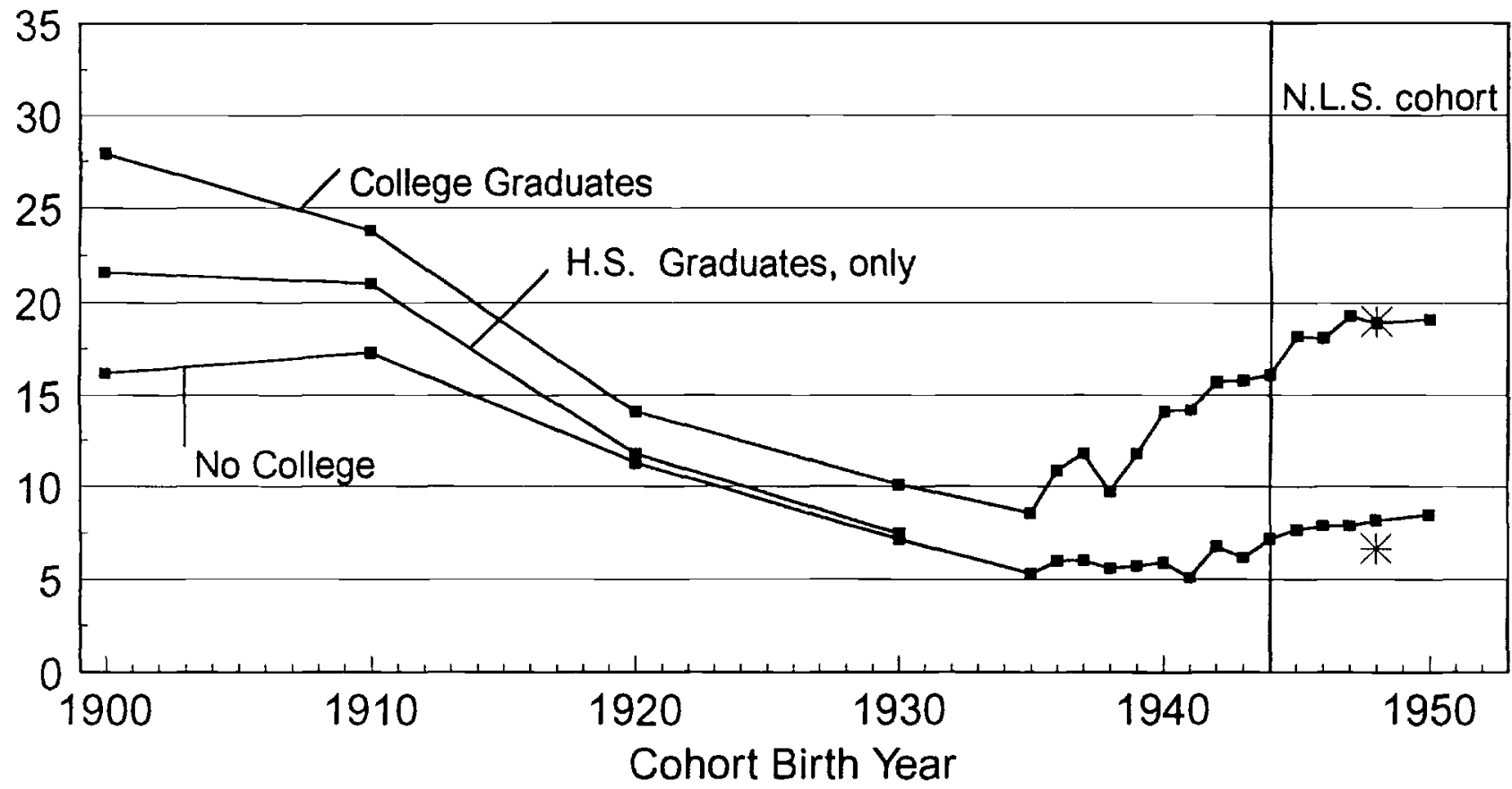

Sources: 1940 PUMS 1/100 sample-line; U.S. Bureau of the Census (1955, 1964, 1973); post-1970: U.S. Bureau of the Census, Current Population Reports, P-20 series, "Fertility of American Women," various dates.

Notes: The stars are for the N.L.S. cohort members for whom a measure of sample participation was non-missing in 1988. College graduates have $\geq 16$ years school completed. 
Figure 5

Percentage of White Women (All Marital Statuses) with No Births by Age 35-44

$\%$ with No Births by Age $35-44$

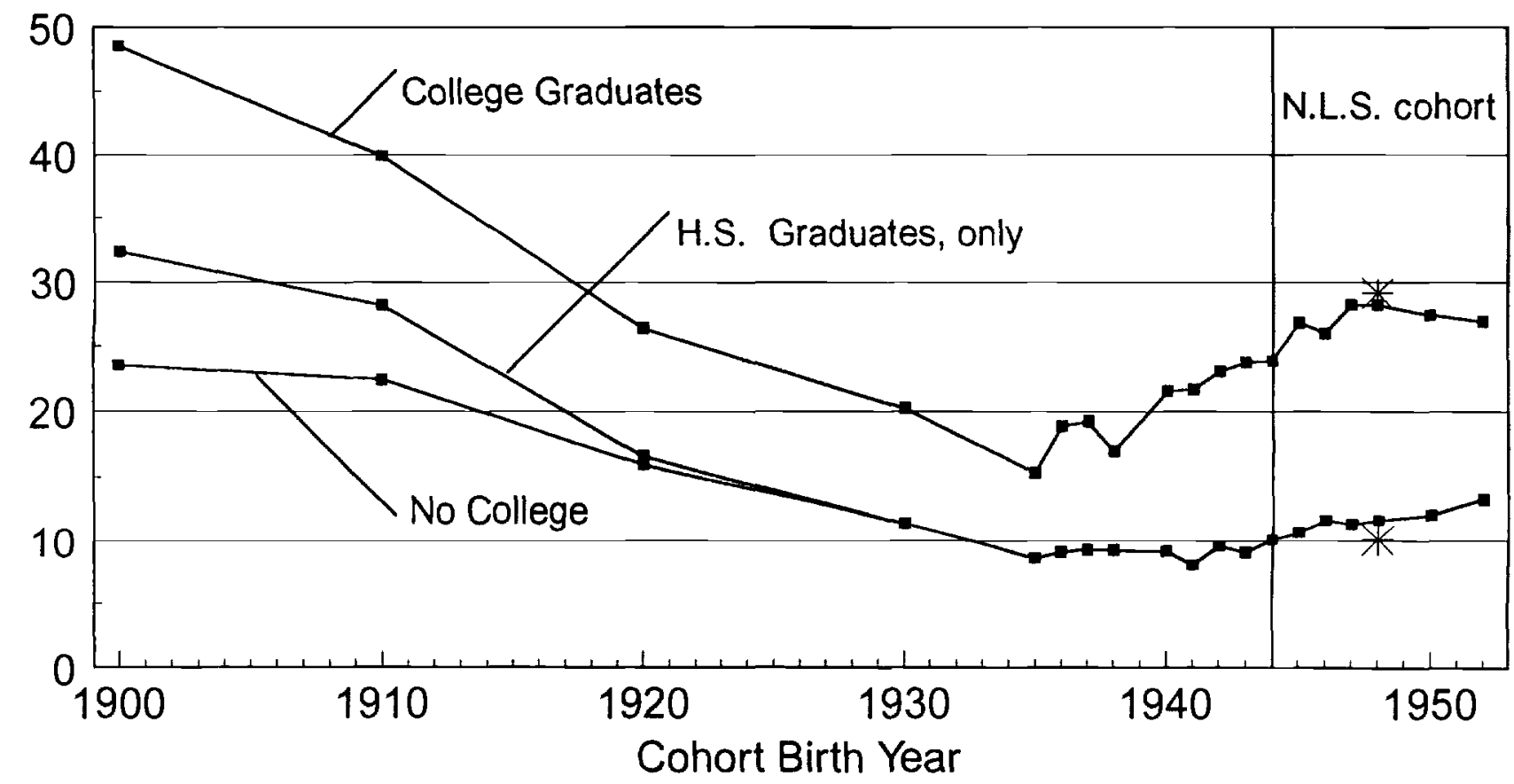

Sources: 1940 PUMS 1/100 sample-line; U.S. Bureau of the Census (1955, 1964, 1973); post-1970: U.S. Bureau of the Census, Current Population Reports P-20 series, "Fertility of American Women," various dates. 1979 has been omitted because the columns in the P-20 series, giving the fraction evermarried, do not sum properly.

Notes: For birth cohorts prior to 1941 the percentage with no births is given by: [(\% with no births among the ever-married) $\times$ (\% ever-married) $]+(\%$ never-married) because birth information was asked only of those who were ever-married. 
Figure 6

Percentage Never Married, College Graduate White Women

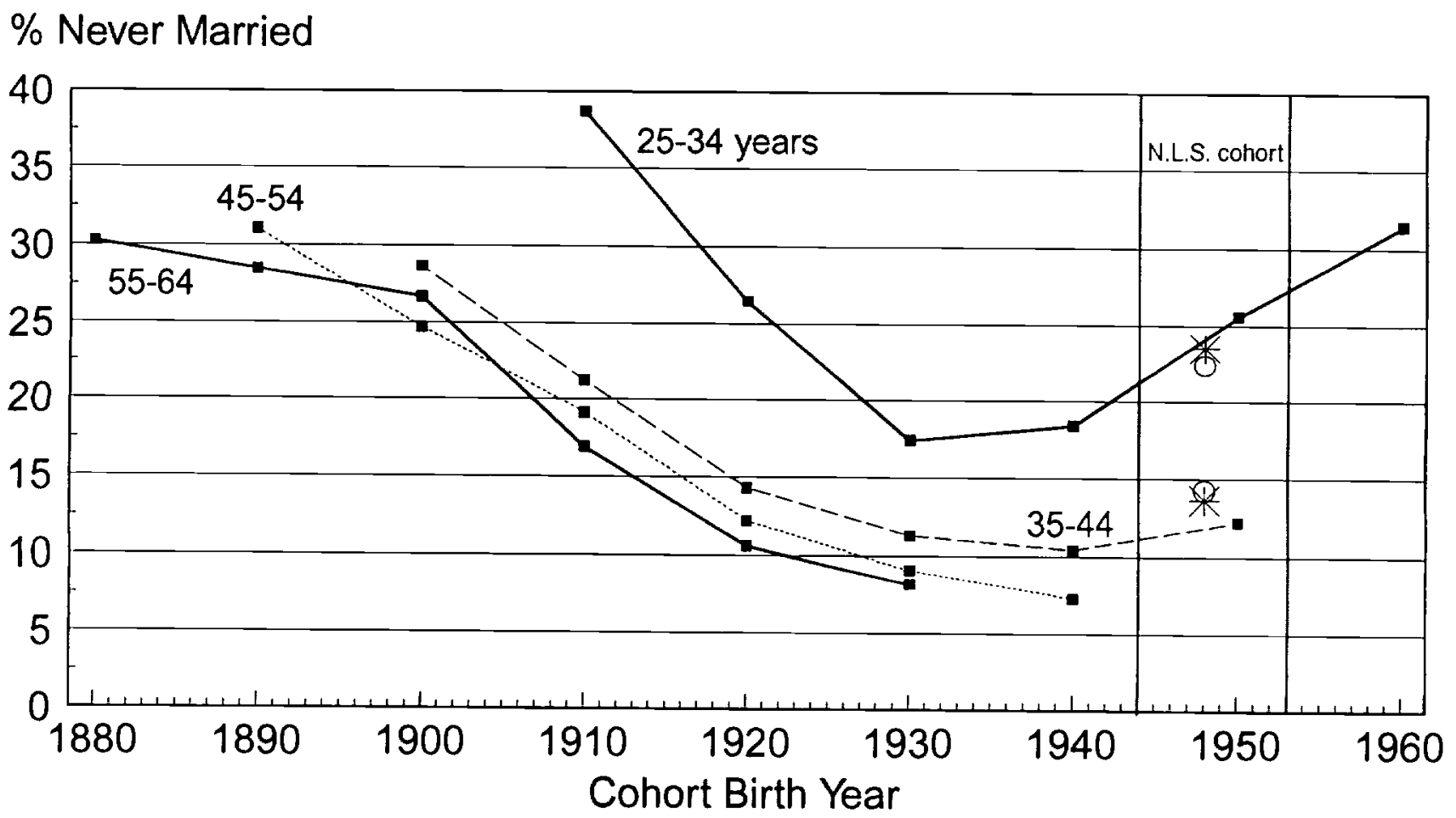

Sources: U.S. Bureau of the Census $(1953,1966,1972,1985)$ and Table 1 for 1940 and 1988/90.

Notes: I do not know why the 55-64 year old figure for the cohort born in 1900 is greater than that for those 45-54 years old. The same reversal appears in the data for those having no college. The stars are for the N.L.S. women with $\geq 16$ years school completed; the circles are for those with a B.A. degree. The census data refers to years of school completed. 
Figure 7

Percentage Never Married, White Women with No College

$\%$ Never Married

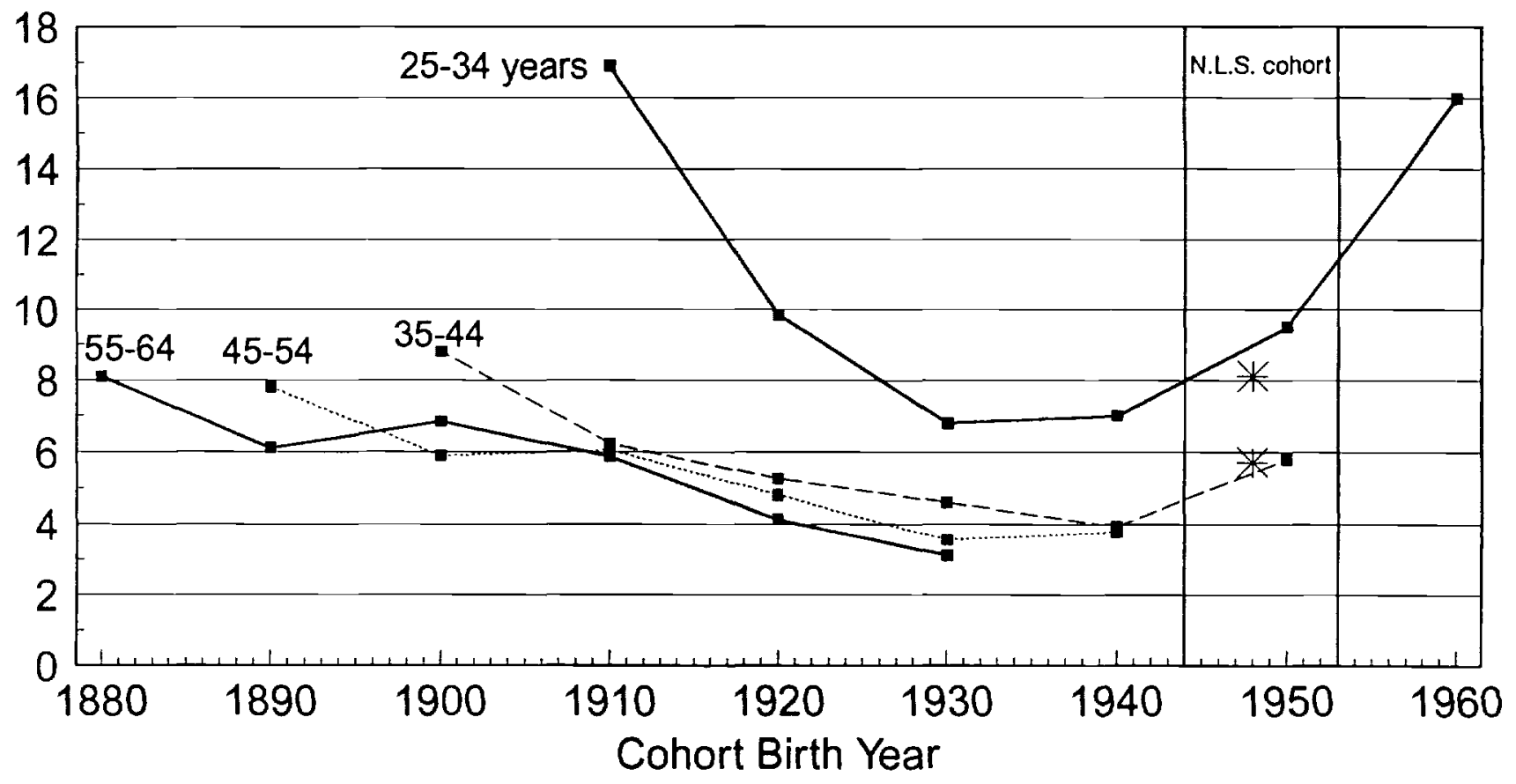

Sources: U.S. Bureau of the Census $(1953,1966,1972,1985)$ and Table 1 for 1940 and 1988/90.

Notes: I do not know why the 55-64 year old figure for the cohort born in 1900 is greater than that for those 45-54 years old. The same reversal appears in the data for those attending college. 
Figure 8

Ratio of Male to Female Undergraduates

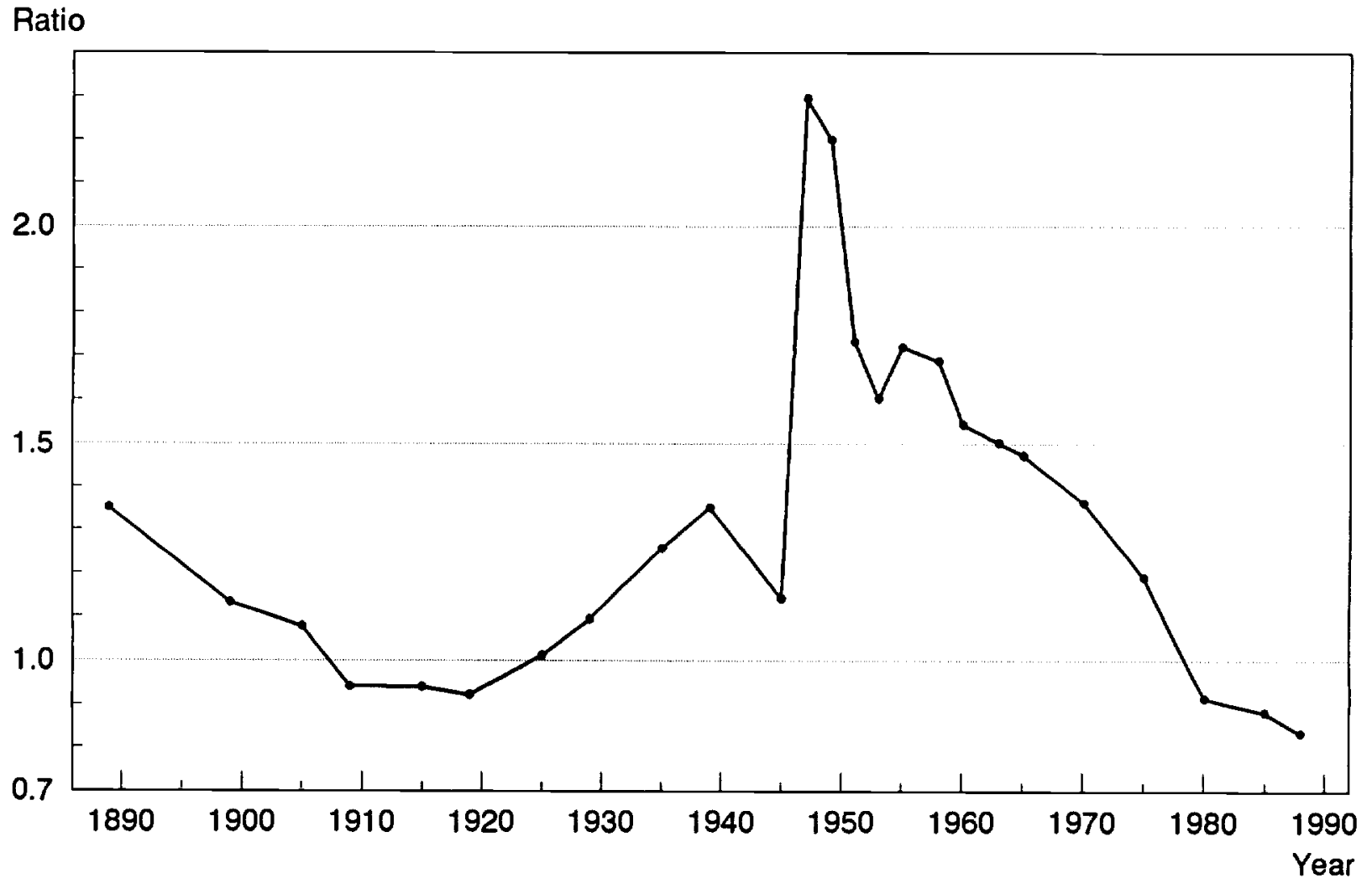

Sources: 1889 to 1953: Bureau of Education or Ofice of Education or U.S. Department of Health, Education and Welfare, Biennial Survey of Education. 1960 to 1965: U.S. Department of Health, Education, and Welfare, Opening (Fall) Enrollment in Higher Education. 1970 to 1988: U.S. Department of Health, Education, and Welfare, Digest of Education Statistics.

Notes: Undergraduate enrollments include colleges, universities, junior colleges or two-year colleges, normal schools, and teachers' colleges. They do not include summer sessions. Parttime and full-time students are treated equally, and some of the rise of female attendance in the most recent period is due to the large enrollment of women who attend college on a part-time basis. Enrollment in graduate school and for professional degrees has been subtracted. Various assumptions have been employed and interpolations used in several years. All underlying data are available upon request from the author. 
Table 1

Characterization of Five Cohorts of College Graduate Women

\begin{tabular}{cccl}
\hline \hline Cohort & $\begin{array}{c}\text { Year Graduating } \\
\text { College }\end{array}$ & $\begin{array}{c}\text { Approximate Birth } \\
\text { Year }\end{array}$ & \multicolumn{1}{c}{ Characterization } \\
\hline I & 1900 to 1919 & 1878 to 1897 & Family or career (attaining) \\
II & 1920 to 1945 & 1898 to 1923 & Job then family (attaining) \\
III & 1946 to 1965 & 1924 to 1943 & Family then job (attaining) \\
IV & 1966 to 1979 & 1944 to 1957 & Career then family (desiring) \\
V & 1980 to 1995 & 1958 to 1973 & Career and family (desiring) \\
\hline \hline
\end{tabular}


Table 2

Percentage Never-Married for (White) Women with $\geq 4$ Years College and No College, 1880 to 1960 Birth Cohorts

\begin{tabular}{|c|c|c|c|c|}
\hline $\begin{array}{c}\text { Approximate } \\
\text { Year of Woman's } \\
\text { Birth }\end{array}$ & $25-34$ & $35-44$ & $45-54$ & $55-64$ \\
\hline
\end{tabular}

\begin{tabular}{|c|c|c|c|c|}
\hline \multicolumn{5}{|c|}{ A. $\geq 4$ Years College } \\
\hline 1880 & & & & 30.3 \\
\hline 1890 & & & 31.1 & 28.5 \\
\hline 1900 & & 28.7 & 24.7 & 26.7 \\
\hline 1910 & 38.7 & 21.2 & 19.1 & 16.9 \\
\hline 1920 & 26.5 & 14.3 & 12.2 & 10.6 \\
\hline 1930 & 17.4 & 11.3 & 9.1 & 8.2 \\
\hline 1940 & 18.4 & 10.4 & 7.3 & \\
\hline 1950 & 25.6 & 12.2 & & \\
\hline 1960 & 31.5 & & & \\
\hline
\end{tabular}

B. No College

1880

8.10

1890

1900

$\begin{array}{lll} & 7.80 & 6.11 \\ 8.80 & 5.90 & 6.85\end{array}$

1910

16.90

6.23

6.06

6.85

1920

9.84

5.26

4.80

5.88

1930

6.80

4.60

4.14

1940

7.01

3.95

3.55

3.11

1950

9.51

5.80

1960

16.00

Sources: 1940 PUMS, 1/100; U.S. Bureau of the Census (1953, 1966, 1972, 1985); 1990 Current Population Survey, Outgoing Rotation Group, NBER-C.P.S. extracts. 
Table 3

Percentage of (White) Ever-Married Women with No Births by Age 35 to 44 Years, for Various Educational Groups

\begin{tabular}{|c|c|c|c|c|}
\hline $\begin{array}{c}\text { Approximate } \\
\text { Year of Woman's } \\
\text { Birth }\end{array}$ & $\geq 4$ Years College & $\begin{array}{c}\text { No College, H.S. } \\
\text { Graduate }\end{array}$ & No College & $>4$ Years College \\
\hline 1900 & 27.9 & 21.6 & 16.2 & n.a. \\
\hline 1910 & 23.8 & 21.0 & 17.3 & n.a. \\
\hline 1920 & 14.1 & 11.8 & 11.3 & 19.4 \\
\hline 1930 & 10.1 & 7.5 & 7.2 & 14.0 \\
\hline 1935 & 8.6 & 5.3 & 5.3 & n.a. \\
\hline 1936 & 10.9 & 6.0 & 6.0 & n.a. \\
\hline 1937 & 11.8 & 6.5 & 6.0 & n.a. \\
\hline 1938 & 9.7 & 6.1 & 5.6 & n.a. \\
\hline 1939 & 11.8 & 5.8 & 5.7 & 16.0 \\
\hline 1940 & 14.1 & 6.2 & 5.9 & 20.6 \\
\hline 1941 & 14.2 & 5.3 & 5.1 & 17.9 \\
\hline 1942 & 15.7 & 7.0 & 6.8 & 20.8 \\
\hline 1943 & 15.8 & 6.7 & 6.2 & 16.5 \\
\hline 1944 & 16.1 & 7.9 & 7.2 & 18.3 \\
\hline 1945 & 18.2 & 8.1 & 7.7 & 22.8 \\
\hline 1946 & 18.1 & 8.5 & 7.9 & 20.4 \\
\hline 1947 & 19.3 & 8.7 & 7.9 & 24.0 \\
\hline 1948 & 18.9 & 8.6 & 8.2 & 23.8 \\
\hline 1950 & 19.1 & 9.6 & 8.5 & 23.9 \\
\hline $1952^{\mathrm{a}}$ & 17.3 & 9.9 & 8.9 & n.a. \\
\hline
\end{tabular}

Sources: U.S. Bureau of the Census (1955, 1964, 1973); U.S. Bureau of the Census, Current a. A change in educational categories accompanied the P-20 series, no. 470, June 1992. There is no longer a category of $>4$ years of college and that for $\geq 4$ years of college has been replaced by B.A. degree or higher. It is unclear whether the change in definition has caused the change in percentage childless or whether there has been an increase in births.

Population Reports, P-20 series, "Fertility of American Women," various dates (latest is No. 470, June 1992).

Notes: All data are for white women only. The educational categories change with the P-20 no. 470 (June 1992). That may account for the decline in no births to women with $\geq 4$ years of college when the other categories increase. 
Table 4

Hourly Earnings in the Current Population Survey and for the N.L.S. Young Women

\begin{tabular}{|c|c|c|c|c|c|c|c|c|c|}
\hline \multirow[b]{2}{*}{ Year } & \multicolumn{3}{|c|}{ Males in C.P.S. } & \multicolumn{3}{|c|}{ Females in C.P.S. } & \multicolumn{3}{|c|}{ Females in N.L.S. } \\
\hline & Median & 25 th & $\mathrm{N}$ & $\underset{n}{\text { Media }}$ & Mean & $\mathrm{N}$ & Median & Mean & $\mathrm{N}$ \\
\hline 1980 & 8.750 & 6.500 & 8977 & 6.528 & 7.245 & 5793 & 6.440 & 6.763 & 355 \\
\hline 1982 & 10.83 & 7.778 & 7887 & 8.108 & 8.896 & 5179 & 7.690 & 8.443 & 342 \\
\hline 1983 & 11.43 & 8.262 & 7753 & 8.750 & 9.562 & 5170 & 8.560 & 9.185 & 345 \\
\hline 1985 & 13.25 & 10.00 & 7781 & 10.00 & 10.98 & 5360 & 9.665 & 10.36 & 350 \\
\hline 1987 & 15.00 & 10.91 & 7577 & 11.00 & 12.10 & 5501 & 11.06 & 11.99 & 345 \\
\hline 1988 & 15.63 & 11.25 & 7175 & 11.25 & 12.68 & 5212 & 12.16 & 12.73 & 340 \\
\hline 1991 & 18.25 & 13.20 & 7155 & 13.50 & 14.82 & 5717 & 15.38 & 15.90 & 349 \\
\hline
\end{tabular}

Sources: Current Population Survey, Outgoing Rotation Group, NBER-C.P.S. Extracts; N.L.S. Young Women.

Notes:

C.P.S.: Ages 14 to 24 in 1968; college graduate $=16$ years attended and completed last year; topcoded values are assigned $1.4 \times$ top amount; hourly earnings is (weekly earnings)/(usual hours worked per week); observation is excluded if hourly earnings $<1 / 2$ relevant minimum wage; race $=$ white. No top code issues are addressed for 1991.

N.L.S.: Same restrictions on education, race, age, use of $1 / 2$ minimum wage on an hourly basis for exclusion. Data are given for observations containing a non-missing value for (computed) job experience in 1985. Hourly earnings in N.L.S. is hourly rate of pay in current or last job derived by the N.L.S. from "rate of pay" and "time unit rate of pay" variables. Various extreme outliers are coded as missing values (but are recoded as their actual values in the computation of the career variables in Table 5). The N.L.S. changed its procedure in 1991 which increased the "rate of pay" by factoring in separate time period information collected from teachers. In both the C.P.S. and N.L.S. earnings excludes that from self-employment. 
Table 5

Career Attainment among College Graduate Women in the N.L.S.

A. Percentage attaining career for white women with $\geq 16$ years school, in the labor force $1985,1987,1988$

\begin{tabular}{lccc}
\hline & Total & $\begin{array}{c}\text { Women with } \\
\text { Children }\end{array}$ & $\begin{array}{c}\text { Women without } \\
\text { Children }\end{array}$ \\
Career: 1987,1988 & $43 \%$ & $35 \%$ & $56 \%$ \\
Career: 1985,1987, & $37 \%$ & $30 \%$ & $47 \%$ \\
1988 & & & \\
& & & \\
\hline
\end{tabular}

B. Percentage attaining career for white women with $\geq 16$ years school, unconditional on labor force participation

\begin{tabular}{lccc}
\hline & Total & $\begin{array}{c}\text { Women with } \\
\text { Children }\end{array}$ & $\begin{array}{c}\text { Women without } \\
\text { Children } \\
\text { Career: } 1987,1988\end{array}$ \\
Career: 1985,1987, & $33 \%$ & $24 \%$ & $54 \%$ \\
1988 & $26 \%$ & $18 \%$ & $45 \%$ \\
& & & \\
\hline \hline
\end{tabular}

Source: N.L.S. Young Women.

Notes: Career is defined as having hourly earnings exceeding that of the 25th percentile male (white, $\geq 16$ years schooling) in the C.P.S. of the relevant year (see Table 4). N.L.S. women are included if they are in the sample for all of the years considered (e.g., 1987 and 1988) and have earnings data that are not missing. The self-employed are excluded from both numerator and denominator, as are those who refused to answer questions on their earnings. Children born to women until the end of the survey (1991, although there are only 17 first-births after 1985) are included. The figures that are unconditional on labor force participation give a zero value to career for women who are out of the labor force in any of the years considered. Women whose hourly earnings are below $1 / 2$ the minimum wage are considered to be out of the labor force. Had they been included in the labor force, the career percentages conditional on labor force participation would be somewhat lower and closer to those unconditional on labor force participation. 
Table 6

Family and Career for Cohort IV: Using Four Definitions of Career and the N.L.S.

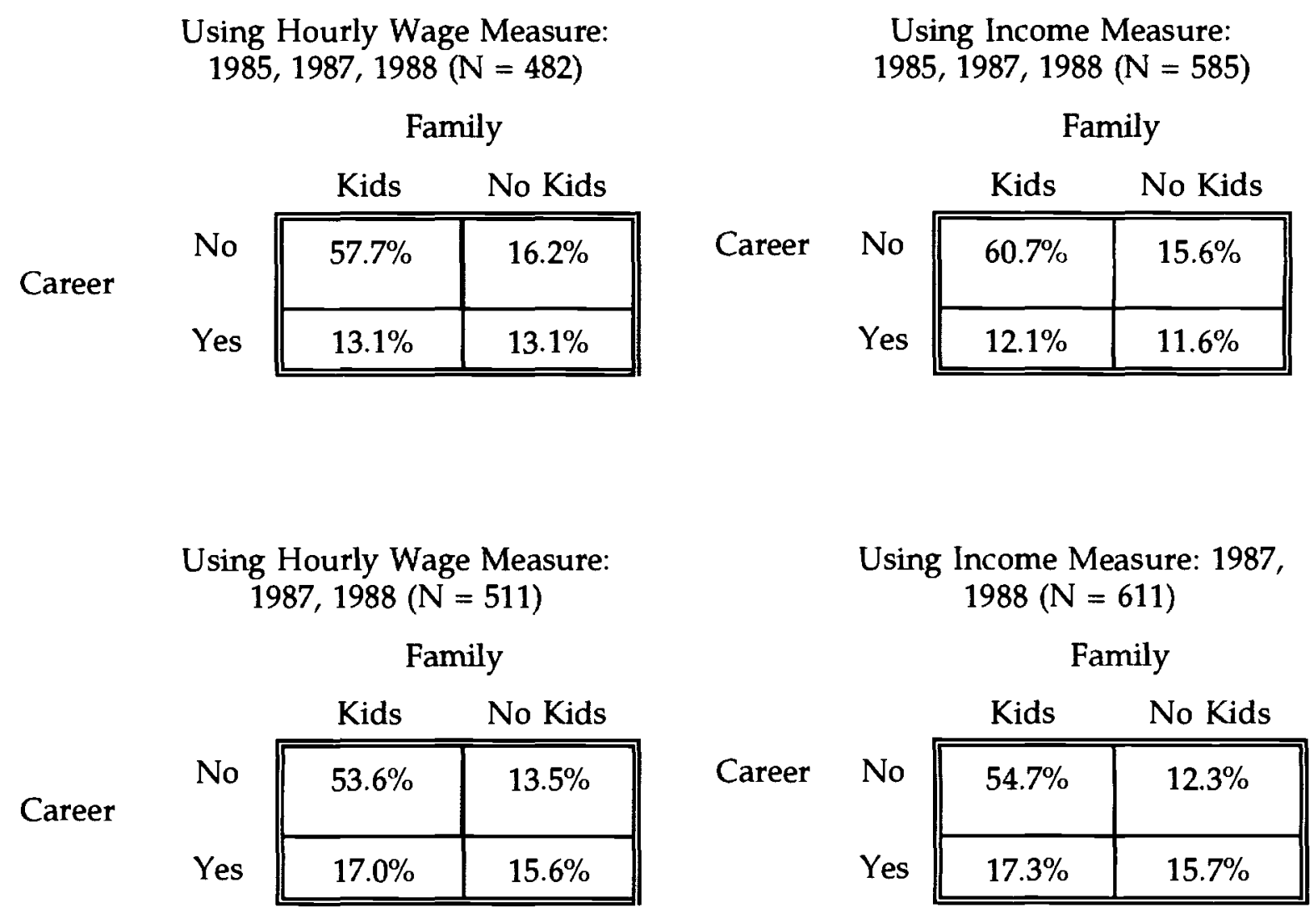

Source: N.L.S. Young Women

Notes: See Tables 4 and 5. The definition of career using income is similar to that using the hourly wage. The cut-off point uses the data for men in Table 4 multiplied by 2,000 hours. Women in the N.L.S. who were self-employed and others with missing hours information are included in the earnings data. Earnings is the aggregate of wage and salary, and business, professional, and farm income. 
Table A1: College Attendance and Graduation Rates by Sex, for Cohorts Born 1875 to 1955 White Males White Females
(1)
(2)
(3)
(4)

(5)

(6)

(7)

Percent Percent Percent Percent

Birth Attending Graduating Attending Graduating

Year College College College College

$\begin{array}{lll} & (2) /(1)- \\ & (4) /(1) & (4) /(3)\end{array}$

$\begin{array}{lrrrrrrr}1875 & 6.4 & 3.4 & 5.5 & 2.0 & .86 & .59 & 16.8 \\ 1880.5 & 7.9 & 4.2 & 7.2 & 2.7 & .91 & .64 & 15.7 \\ 1887.5 & 9.6 & 4.6 & 8.7 & 3.3 & .91 & .72 & 10.0 \\ 1890.5 & 9.5 & 5.0 & 8.9 & 3.4 & .94 & .68 & 14.4 \\ 1897.5 & 11.4 & 5.8 & 11.8 & 4.3 & .97 & .74 & 14.4 \\ 1902.5 & 15.8 & 9.2 & 15.4 & 6.2 & .97 & .67 & 18.0 \\ 1904.5 & 17.4 & 10.5 & 15.8 & 7.2 & .91 & .69 & 14.8 \\ 1906.5 & 17.1 & 9.7 & 16.8 & 7.8 & .98 & .80 & 10.3 \\ 1908.5 & 18.2 & 9.8 & 17.0 & 7.9 & .93 & .78 & 7.4 \\ 1912.5 & 19.7 & 9.9 & 17.4 & 7.3 & .88 & .74 & 8.3 \\ 1914.5 & 20.7 & 11.0 & 17.5 & 7.7 & .85 & .70 & 9.1 \\ 1916.5 & 20.0 & 11.0 & 16.6 & 7.3 & .83 & .66 & 11.0 \\ 1918.5 & 23.3 & 12.6 & 16.8 & 7.1 & .72 & .56 & 11.8 \\ 1920.5 & 25.4 & 13.9 & 17.4 & 7.6 & .69 & .55 & 11.0 \\ 1924.5 & 29.1 & 17.0 & 19.4 & 8.6 & .67 & .51 & 14.1 \\ 1927 & 31.9 & 19.2 & 22.9 & 10.6 & .72 & .55 & 13.9 \\ 1930 & 33.1 & 20.1 & 23.6 & 11.2 & .71 & .56 & 13.3 \\ 1933 & 37.9 & 24.2 & 28.3 & 14.0 & .75 & .58 & 14.4 \\ 1935 & 38.4 & 24.2 & 28.6 & 12.9 & .74 & .53 & 17.9 \\ 1938 & 39.7 & 24.1 & 30.3 & 15.0 & .76 & .62 & 11.2 \\ 1940 & 43.8 & 26.6 & 34.4 & 16.4 & .79 & .62 & 13.0 \\ 1943 & 47.9 & 29.6 & 37.5 & 18.4 & .78 & .62 & 12.7 \\ 1945 & 50.7 & 31.6 & 41.4 & 22.3 & .82 & .71 & 8.5 \\ 1948^{\mathrm{a}} & 59.2 & 36.9 & 55.0 & 30.7 & .93 & .83 & 6.5 \\ 1950^{\mathrm{a}} & 59.7 & 34.4 & 55.7 & 28.8 & .93 & .84 & 5.9 \\ 1954^{\mathrm{a}} & 52.5 & 29.7 & 53.3 & 28.1 & 1.02 & .95 & 3.9 \\ 1955^{\mathrm{a}} & 50.3 & 30.4 & 54.0 & 28.6 & 1.07 & .94 & 7.5\end{array}$

a Projections to 1995 or 1997 based on the experiences of the previous cohorts.

Sources: U.S. Bureau of the Census, Current Population Reports, Series P-20, Educational Attainment in the United States, various numbers, (Washington, DC: Government Printing Office, various dates).

Notes: In virtually all cases only the responses of individuals 45 to 54 or 55 to 64 years old were used. For cohorts born since 1945 projections were made to 1995 or 1997 on the basis of changes for the preceding cohort that was 35-39 (30-34) years in 1977 and 45-49 (40-44) years in 1987. 